\title{
Shaping sustainable markets: A conceptual framework illustrated by the case of biogas in Sweden
}

Mikael Ottosson, Thomas Magnusson and Hans Andersson

The self-archived postprint version of this journal article is available at Linköping University Institutional Repository (DiVA):

http:/ / urn.kb.se/ resolve?urn=urn:nbn:se:liu:diva- 162107

N.B.: When citing this work, cite the original publication.

Ottosson, M., Magnusson, T., Andersson, H., (2019), Shaping sustainable markets: A conceptual framework illustrated by the case of biogas in Sweden, Environmental Innovation and Societal Transitions. https:// doi.org/ 10.1016/j.eist.2019.10.008

Original publication available at:

https:/ / doi.org/ 10.1016/j.eist.2019.10.008

Copyright: Elsevier

http:// www.elsevier.com/

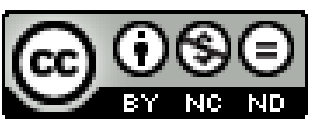




\section{Shaping sustainable markets - a conceptual framework illustrated by the case of biogas in Sweden}

\section{Abstract}

By merging findings from transition studies with recent literature on market-shaping, this paper outlines a conceptual framework that describes the shaping of sustainable markets. The framework comprises three critical processes: enabling exchange practices, proving the system and constructing the narrative. Individually, these processes generate different kinds of value - traded, demonstrated and expected value - and the value output from each process serves as input to the other two processes. Hence the value streams link the processes together. We illustrate the framework by analyzing market-shaping processes for biogas in Sweden. The case analysis shows how public and private actors have engaged in a multitude of activities in the market-shaping processes. The analysis highlights the recursive nature of sustainable market-shaping, showing how key actors must repeatedly respond to tensions resulting from growth and aspirations of growth.

Keywords: Market-shaping, transition, market formation, biogas, value, sustainable markets 


\section{Introduction}

Transition studies often refer to strategic niche management (SNM) and the technological innovation systems (TIS) approach when analyzing how renewable and low-carbon technologies can reach a market. SNM points towards niches as important protective spaces that facilitate alignment between nascent technologies and societal expectations (Kemp et al., 1998; Schot and Geels, 2007; Schot and Geels 2008). Jacobsson and Bergek (2004) analyzed the emergence of technological systems for renewable energy, distinguishing between an early formative phase and a subsequent phase characterized by positive feedback and growth. They claimed that niches that facilitate market entry are important to proceed from the formative phase. In a later elaboration of the TIS approach, they described market formation as a process consisting of "three phases with quite distinct features": nursing markets (niches), bridging markets, and mass markets (Bergek et al., 2008a, p. 416). However, the TIS approach has attracted criticism for paying insufficient attention to agency and the sociopolitical struggles associated with transitions. According to Kern (2015), this lack of attention has limited the explanatory value of the approach. In response, Markard et al. (2015, p. 82) "agree with Kern (2015) that more emphasis may be placed on politics in analyses of TIS dynamics”.

Marketing scholars agree with sustainability transition scholars on the need to address agency and politics in market analyses. Whereas markets historically have been seen as pre-existing arenas waiting to be exploited by firms, recent marketing literature perceive markets as dynamic systems, which are constantly shaped by a variety of actors (Mele et al., 2015; Harrison \& Kjellberg, 2010; Storbacka \& Nenonen, 2015). According to Ulkuniemi et al. (2015, p. 55) "markets can be examined through actors ... and their actions”. This literature suggests that actors shape markets through their attempts to influence other actors (Kindström et al., 2018; Nenonen et al. 2019). These attempts involve different activities, ranging from traditional promotion to activities that involve entire systems, changing the institutional and technical structures that restrict and regulate market behaviors (Kjellberg and Helgesson, 2007; Mele et al., 2015).

According to Mazzucato (2016), governments are lead actors in the shaping of sustainable markets. She claims that there is a need for new types of public policies to address sustainability transitions; rather than remedying system failures, governments must act to shape markets (Mazzucato and Semieniuk, 2017). Mazzucato’s perspective is that of the national state, arguing that 'the entrepreneurial state' can shape markets through public investments (Mazzucato, 2013). However, Mackenzie (2009) discussed how the politics of market-shaping go beyond the entrepreneurial state and involve what Beck (1997) referred to as 'subpolitics'. Multiple actors engage in subpolitics outside and beyond the representative institutions of the political system of nation states. For example, Doganova and Karnoe (2015) discussed how collaborations of scientists, corporations, and other organizations play an increasing role in markets for clean technologies, as these markets are situated in between political, economic, and scientific issues. Hence, in order to analyze sustainable markets, there is a need to consider a broad variety of actors and their activities (cf. Mortensen, 2018; Meadowcroft, 2011; Smith and Raven, 2012; Geels et al., 2016).

Even though transition researchers and market-shaping researchers agree on the need to address various kinds of actors, these respective research areas tend to take different 
perspectives. Whereas most transition studies have been conducted on a meso-level (Köhler et al., 2019), market-shaping studies have often taken the perspective of the focal business firm (e.g. Jaworski et al. 2000, Kindström et al, 2018). The differing perspectives result in diverse ways of attributing agency and providing advice. Whereas transition approaches such as TIS and SNM primarily have been outlined to give policy implications (e.g. Bergek et al., 2008; Hekkert et al., 2007; Schot and Geels 2008), market-shaping research focuses on implications for business management (e.g. Kindström et al., 2018; Nenonen et al., 2019; Ulkuniemi et al., 2015). Still, transition scholars agree that businesses and firms play important roles in sustainability transitions (Köhler et al., 2019). Hence, these two fields of research can offer useful complementary perspectives.

By integrating concepts from recent market-shaping literature with insights from transition studies, this paper outlines a conceptual framework that advances an understanding of the shaping of sustainable markets. The framework comprises three critical market-shaping processes: enabling exchange practices, proving the system, and constructing the narrative. These processes generate different kinds of value and their respective value streams link the processes together. We illustrate the framework by analyzing market-shaping processes for biogas in Sweden. In terms of biogas, Sweden stands out from other European countries in its preference to produce upgraded biogas (often referred to as biomethane) and use it as a vehicle fuel. In 2017, 65 percent of the nationally produced biogas was upgraded and used in such applications; no other European country comes close to this (EC, 2017). An important explanation is the consistent support through market-stimulating policies, which are quite different from most other European countries. We base the case study on data from the early 1990s to 2019, with a focus on the last decade, a period that has been marked by growth as well as expectations of considerable future growth. By studying how a range of public and private actors have engaged in a variety of activities, the paper addresses the following question: How are sustainable markets being shaped?

Following this introduction, the paper proceeds with a conceptual section that presents a market-shaping framework. This is followed by a methods section where we explain the research design. The subsequent section illustrates the framework by means of the case analysis. A discussion section then summarizes the lessons of the case study and a concluding section condenses the main conceptual findings and implications. 


\section{Shaping sustainable markets}

This conceptual section combines recent market-shaping literature with findings from transition studies to outline a framework for the shaping of sustainable markets.

\subsection{Markets and value}

Markets can be defined as value-creating structures (Vargo and Lusch, 2004). Whereas a traditional perspective of markets implies some type of competition, involving several buyers and sellers as well as a pricing process that regulates the monetary value of the exchange (Ahrne et al., 2015), some scholars disagree about “... where and how value is created and about the role of the exchange in the value-creation" (Chandler and Vargo, 2011, p. 35). Many contemporary marketing scholars emphasize that “... exchange and perceptions of value are embedded in social systems...” (Edvardsson et al., 2011, p. 328), where actors connect and trade resources with the intention of creating value in a given context (Håkansson and Snehota, 2017). Whereas price is what a buyer pays for a product, value is what a user obtains from using that product. As studies on the diffusion of solar photovoltaics in Germany (Dewald and Truffer, 2011) have illustrated, a product can be more valuable in one context and less valuable in another.

In recent years, market-shaping research has advanced an understanding of markets as dynamic systems rather than fixed entities (Mele et al., 2015; Kjellberg and Helgesson, 2007). Hence, rather than considering markets as pre-existing entities somewhere 'out there', markets are increasingly viewed as ongoing processes that actors can influence, and therefore shape, through various activities (Nenonen et al 2019, Kjellberg et al. 2015). Inherent in this view is an emphasis on different actors as co-creators of markets, as opposed to the view of producing firms targeting predefined markets for their products (Storbacka and Nenonen, 2011). Thus, market-shaping research emphasizes the importance of looking at actors' activities to understand market-shaping processes (see, e.g., Kindström et al., 2018; Nenonen et al 2019; Ulkuniemi et al., 2015).

Following this view, markets are being shaped as actors engage in various activities and interactions that change the market structure (for example, buying competitors or getting new players to enter the market) and the market behavior (for example, altering customer preferences) (Jaworski et al., 2000). Consequently, literature on market-shaping provides an overarching concept that allows us to identify dynamic processes by analyzing market actors and their activities.

\subsection{Enabling exchange practices}

Enabling exchange practices refers to the facilitation of trade. A prerequisite for trade is that market actors can agree on a monetary value of the exchanged resources. Kjellberg et al. (2013) argued that products do not have predetermined values; rather, value is an outcome of active and ongoing exchanges. Concrete activities related to supply and demand typically represent these exchanges. This entails negotiation of price, functionality, quality, payment and terms of delivery (Ottosson and Kindström, 2016). Whereas activities involving buyers and sellers, situated at various places along the supply chain, are critical for this process to unfold, governments may interfere with the intention to stimulate forms of trade that they consider beneficial for the society. 
Suppliers of products and services often divide the markets they serve into different segments, which describe different areas of application and user profiles. Analyzing the diffusion of solar photovoltaics in Germany, Dewald and Truffer (2017) argued that it is important to establish dedicated supply structures for different segments. It is also important to interact with the demand side in order to understand individual user preferences.

To justify their investments, market actors must calculate returns and estimate risks. Judgments will depend on projections of future technical and market developments, competition and sales volumes, as well as possible synergies and scale economies (Muniesa et al., 2007; Sushandoyo and Magnusson, 2014). Based on studies of biomass gasification and offshore wind power in Europe, Karltorp (2016) submitted that limited access to investment capital due to high-risk estimates and low expected returns remains a significant hurdle for technology diffusion. According to Mazzucato and Semieniuk (2017), governments therefore need to take significant responsibility for the facilitation of investments to shape sustainable markets. Complementary financing such as governmental investment subsidies is required to attract private investment capital. Consequently, exchange practices depend on activities involving both public and private actors at the intersection of product and financial markets.

\subsection{Proving the system}

Proving the system refers to the process of establishing material and organizational arrangements that facilitate production, distribution, and use. These arrangements show that value creation is possible. The systems engineering literature uses the concept of validation to describe activities to ensure that the technical system fulfills specified requirements, standards, and intended functionality demands (Blanchard et al., 1990). In the development and implementation of new technologies, it is particularly important to consider relationships with established systems, as observations from the expansion of wind power in Denmark exemplify. According to Mortensen (2018, p. 74-75), Danish wind power advocates have repeatedly had to present evidence against the argument that “...too much wind power could cause electricity overrun, which would be costly in terms of lost revenue and technological costs to secure against Black-out Risk.”

Drawing on concepts introduced by Hughes (1983), transitions literature uses the term 'sociotechnical systems' to describe such dynamic interactions between actors and technology. Hughes described energy systems as a mix of technology, organizations, and institutions, suggesting that these systems constitute a 'seamless web' involving both technical and social aspects. The establishment of such systems depends on certain actors that take a systembuilding role, orchestrating the development of systems that facilitate production and use. Geels (2004) argued that the concept of institutions is essential for understanding the development of socio-technical systems. Institutions refer to norms, standards, and regulations that set boundaries for market actors (Edvardsson et al., 2014). Existing institutional frameworks will influence the possibilities for new alternatives; innovative technologies and products must comply with relevant institutions to be legitimate (Bergek et al., 2008b). In their studies of biogas in Austria, Wirth et al. (2013) highlighted the importance of informal institutions, while Markard et al.'s (2016) research into biogas in Germany found that rapid expansion of technical systems could result in problems with social acceptance. However, institutions can be shaped and acted upon (Koskela-Huotari et al., 2016). Vargo et al. (2015) demonstrated that it is possible to influence institutions through 
processes that involve actors such as industry associations, national governments and different public authorities, as well as individual companies. Actors who can influence relevant institutions will have a strong influence on market-shaping (cf. Edvardsson et al., 2014).

\subsection{Constructing the narrative}

Constructing the narrative refers to a process of discursive activities. Besides promotion, this process also includes attempts to shape markets through information campaigns and lobbying. Critical for this are actors' attempts to qualify desirable attributes and characteristics to the product (Callon et al. 2002). According to Finch and Acha (2008), actors need to define the product through interactive processes. This is because perceptions of value may differ (Harrison and Kjellberg, 2016). Kjellberg and Helgesson (2007) termed such activities as normalizing practices since they are intended to shape market norms. Correspondingly, transition scholars have argued that actors' discursive strategies are critical to raise expectations and mobilize resources. Smith (2007) argued that there is a need for niche-regime translations because, while niches represent new alternatives regimes control resources that can facilitate or hamper further development and growth. Studies of vehicle manufacturers' technology strategies suggest that established firms (incumbents) can act as translators, making business sense of new options (Berggren et al., 2015).

Analyzing the case of fuel cells in Germany, Musiolik and Markard (2011, p. 1920) showed how networks of actors "tried to shape collective expectations and the reputation of the novel technology in a positive way”. Negro et al. (2008) argued that the demise of biomass gasification in the Netherlands was partly due to the absence of advocacy coalitions speaking in favor of the technology. Based on studies of British and Dutch offshore wind power, Kern et al. $(2014 ; 2015)$ emphasized the role of narratives in the shaping of expectations. Narratives are socially constructed stories that have an underlying moral. According to Søderberg (2003), narratives focus on human action and provide interpretations from a specific point of view; thus constituting essential elements in the construction of shared identities.

Discussing how actors envision future systems, Smith and Raven (2012) argued that actors use narratives to make claims about innovative technology alternatives and their attributes. Narratives may either claim that innovative technology alternatives correspond to existing system structures, or that structural transformation is necessary to accommodate them. In their analysis of low-carbon technologies in the UK and the Netherlands, Raven et al. (2016) pointed towards the complex relationships between narratives and sociopolitical agendas, showing the importance of linking the narrative to prominent debates in society. In a study of the development of bio-refineries, Bauer (2018) showed that several and even conflicting narratives may be used to justify investments and growth. Moreover, in their studies of renewable energy in Germany, Lauber and Jacobsson (2016) revealed controversies between actors promoting different narratives and showed how their influence may vary over time. 


\subsection{A framework for shaping sustainable markets}

Summarizing the theoretical discussion, figure 1 distinguishes the three processes that are critical for the shaping of sustainable markets: enabling exchange practices, proving the system, and constructing the narrative. Different value outputs distinguish these marketshaping processes.

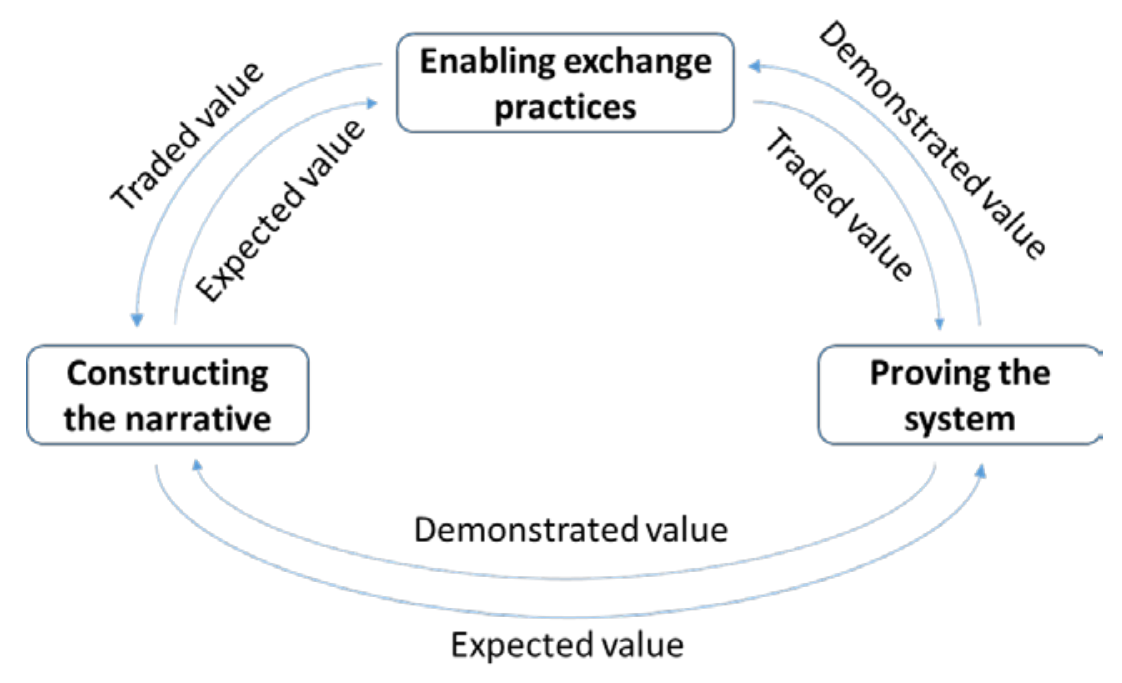

Figure 1. Framework for the shaping of sustainable markets, highlighting critical processes and value flows.

As noted by Pettigrew (1997), processes consist of activities carried out by actors. Following this definition, enabling exchange practices refers to activities that facilitate trade. The trade comprises a supply side and a demand side; the ability of sellers and buyers to agree on a price determines the viability of the exchanges. The price represents a monetary value, which both parties accept at the time of the exchange. For the seller, the exchange of resources for money implies a realization of value, but for the buyer the value will not become realized until (s)he uses the resource or sells it further to another actor. Still the transaction means that the resource has a traded value. The same goes for investments. Investors expect that the money spent on facilities, machinery, infrastructure etc. will generate certain returns in the future. In exchange of the possibilities to attain these returns, they accept certain risks. Thus, an investment implies a monetary valuation of an expectation; it shows that the investor has deemed the risk worthwhile. The production, distribution and use of resources may have positive or negative societal effects and negotiations between sellers and buyers do not necessarily consider the full value of such externalities. Governments may compensate for this by means of subsidies. Such compensation is particularly relevant for technologies that can help build more sustainable societies. Thus, governments agree to absorb certain costs with the intention to affect other actors' decisions.

Proving the system includes activities carried out with the intention of establishing functioning systems. This includes experimenting with technical solutions, and validating their functionality and compliance with norms, standards, and requirements. Such activities may provide valuable feedback that stimulates further system-building, but they may also demonstrate the need to alter established systems to be able to benefit from innovative technologies. Essential for the system-proving process is the provision of resources necessary 
to operate the system, as well as the actual production and use of product(s). The value output of these activities is demonstrated value; that is, arrangements that show how the sociotechnical system can generate value for the involved actors. While producers, distributors, and users are central in this market-shaping process, a wide range of actors may be involved.

Constructing the narrative refers to activities intended to raise expectations. Through narration, advocates make the innovative technology comprehensible, plausible, and attractive. The constructed narrative describes an expected value that actors can use to justify structural changes, institutional reforms, purchases and investments. A convincing narrative makes it possible for actors to accept, embrace, and support new technologies and it therefore serves to enroll actors. The story constructed through the narration offers an identity that serves as a basis for advocates to gather in socio-technical associations and advocacy coalitions in support of the new alternative.

The value outputs from each process (traded, demonstrated and expected value) provide inputs to the other processes. Thus, the three market-shaping processes are interrelated through value flows that may provide both positive and negative feedback loops. This means that recursive processes shape markets. Markets are performed rather than given. 


\section{Research methods}

This paper uses a case study to illustrate the market-shaping framework outlined in the preceding section. We start this section by motivating our research approach and explaining the rationale for case selection. We then describe the methods used for data collection and analysis.

\subsection{Case study design}

Case study research offers a possibility to reveal contextually embedded complex processes by investigating the intricate activities they consist of (Eisenhardt and Graebner, 2007). As our research explores and identifies context-bound activities conducted by a heterogeneous group of actors, we deemed this to be an appropriate research approach. Nenonen et al. (2019) chose a similar method for studies of market-shaping, motivating their choice by the complex and situated character of market-shaping processes, describing a variety of activities involving different actors. Also, the fact that a recent analysis of the biogas development in an Italian region was based on a case study (Cavicchi, 2016) strengthens this choice of this research approach.

\subsection{Case selection}

We based our case selection on theoretical sampling, highlighting the special characteristics of the case (Eisenhardt and Graebner, 2007). Because biogas production presents potential solutions to environmental problems such as air quality, greenhouse gases, nutrient recirculation, organic wastes, and wastewater (Lantz et al., 2007), it is highly relevant for sustainability transitions (e.g., Wirth et al., 2013; Markard et al., 2016). By means of biogas production, organic wastes from sewage water, food residues and manure, as well as residues from industrial production are turned into valuable products - renewable fuel and biofertilizers. This suggests that biogas could help solving many sustainability problems, but it also demonstrates the complexity of a biogas system, involving actors from a variety of sectors such as energy, transport, agriculture, sewage and solid waste management.

Because different organic substrates are used as inputs for biogas production, there is a significant variation of the methane concentration at different plants. Therefore, biogas producers often use the biogas for electric power and/or heat generation at their own facilities. However, upgrading the biogas to raise its methane content makes biogas equivalent to natural gas. This upgrading enables trade of biogas, which opens a range of applications, such as using it as a fuel for vehicles designed for compressed natural gas (CNG) or as a substitute for natural gas in industrial processes. As mentioned above (1. Introduction), Sweden has an exceptionally high degree of biogas upgrading. Biogas in Sweden thus constitutes a suitable case for an analysis of market-shaping.

\subsection{Data collection and analysis}

The variety of actors and activities involved in Swedish biogas market-shaping made it necessary for us to base the case analysis on data gained from various sources. We conducted the empirical studies through a five-year engagement in a multi-stakeholder and crossdisciplinary research center on biogas - Biogas Research Center. The research approach is similar to what Van de Ven and Johnson (2006) denoted as ‘engaged scholarship’ (see also Wells and Nieuwenhuis, 2017). The focus was on collaborative forms of co-production of knowledge in which researchers and practitioners leveraged their different perspectives, 
experiences, and competencies. We attended several multi-stakeholder workshops, seminars, presentations, and study visits. Table 1 in Appendix 1 presents a list of the events that we attended. The participants at these events represented a wide array of actor categories and the events covered a broad range of biogas-related topics.

We triangulated the qualitative data gained from the longitudinal stakeholder interaction with quantitative data obtained from the Swedish Energy Agency (see Appendix 2). The Swedish Energy Agency collects this data as a basis for annual biogas reports on the status and development of the national biogas production. We obtained the raw data used for these reports. At the level of individual plants, the data includes detailed information on production volumes, production technologies, substrates, and use of the biogas. We also gained secondary data from vehicle registration and gas distribution statistics, newspapers, academic and industrial journal articles, consultancy reports, government reports and bills, press releases, and advertising campaigns.

Moreover, we conducted interviews with representatives from 15 different market actors. The respondents comprise key personnel from the Swedish ministry of the environment and energy, energy utilities, suppliers of biogas equipment, biogas producers, vehicle manufactures, gas grid owners, biogas distributors, lobbyists, and think tanks. We primarily targeted actors that were not regularly involved in the research center. The rationale for this sample profile was to minimize the scope for bias inherent in the answers from individual respondents or organizations. All interviews were semi-structured by means of interview guides. The interviews were generally audio-recorded and conducted face-to-face on-site. Two respondents asked to remain anonymous, so we could not record these interviews on ethical grounds. We conducted the interviews between 2014 and 2019 and each interview lasted between one and two hours. Table 2 in Appendix 1 presents an overview of the interviews.

The involvement in the multi-stakeholder and cross-disciplinary Biogas Research Center, as well as participation in multi-stakeholder events, facilitated recurrent interaction with key actors in Swedish biogas market-shaping. This enabled us to develop our framework and refine our case analysis over a five-year period. The case study analysis was characterized by an iterative matching of theory, practice, research direction, and case delimitation, an analytic approach that Dubois and Gadde (2002) denoted as 'systematic combining'. The approach relies on an evolving theoretical framework, which the researchers repeatedly confront with empirical case study findings from different data sources. Our repeated involvement with practitioners and the emerging conceptual logic of the theoretical constructs jointly served to guide our analysis and validate the research results. 


\section{Case analysis - market-shaping processes for biogas in Sweden}

This section presents the case analysis. It follows the three market-shaping processes outlined in Section 2 (Figure 1): enabling exchange practices, proving the system and constructing the narrative.

\subsection{Enabling exchange practices}

The Swedish Government has implemented several policy instruments in support of biogasrelated investments and trade. In a retrospective analysis of various policy instruments, Larsson et al. (2016) singled out two specific subsidy schemes as the most influential: governmental investment grants and tax exemptions for the use of biogas as a vehicle fuel. Because fossil vehicle fuels are subject to heavy taxation in Sweden, the fuel-tax exemption has enabled biogas producers to offer their product at a price that vehicle users can accept. At the EU level, the Swedish Government has had to justify this exemption because it breaks European competition regulations. The exemption has been in place since 2004 and the European Commission has only permitted it on a temporary basis, making it subject to repeated renegotiations. This has resulted in uncertainties, which have had negative effects on the willingness to make long-term investments (Lönnqvist et al., 2017). Moreover, the differences between the Swedish subsidy scheme and those of other European countries have resulted in skewed competition. Whereas Swedish biogas has only benefitted from domestic tax exemptions, imported biogas has sometimes benefitted from both production subsidies and fuel tax exemptions. This has had negative effects, particularly on Swedish biogas producers along the south and west coasts, which are served by a gas transmission pipeline that runs from Denmark.

Close to the gas pipeline, the municipal energy company Göteborg Energi have built a largescale demonstration and research facility called GoBiGas. This facility is one of the most significant individual biogas investments in Sweden. Unlike traditional biogas production where organic substrates are digested into biogas, the idea was to produce biogas through thermal gasification of residues from forestry such as peaks and branches, and sell the gas to customers by the transmission pipeline. The plan was that GoBiGas 1 would be followed by a much larger facility, GoBiGas 2, which would fully commercialize the technology. Our respondent at Göteborg Energi justified the decision to invest in the Gobigas gasification plant around 2009 as follows: “... we had a bull market that was growing by $20-30$ percent annually”. They calculated that the demand would continue to grow and consequently prices would rise. These projections did not materialize because of falling energy prices and competition from double-subsidized biogas imports. Thus, Gobigas suffered from heavy operational losses, which eventually forced Göteborg Energi to mothball the plant.

The ownership structure suggests that Swedish municipalities have assumed the lion's share of the biogas production investments so far (see Appendix 2). Besides municipal utilities, there is also active involvement from gas incumbents. This includes the owner/operator of the gas transmission pipeline, as well as established gas distributors. For them, biogas presents an opportunity to make their product "green" and to differentiate their products, selling different mixes of biogas and fossil natural gas. There are currently over 170 public filling stations for compressed gas and 60 non-public stations, mostly at bus depots (see Appendix 2 for data on delivered gas volumes). Three large multinationals dominate the distribution. The energy corporation Eon operates mainly in the southern part of the country, and the gas supplier AGA - part of the Linde Group - in the Stockholm region. Operating primarily in the western 
part of the country, Göteborg Energi founded the distribution company Fordonsgas, which Air Liquide subsequently acquired. Other than these three gas incumbents, there are a few small local distributors specializing in biogas, such as the municipality owned Svensk Biogas, which operates in the eastern part of the country.

Supply via bus depots has been very important for Swedish biogas sales (see Appendix 2). However, the number of public transport buses is limited, and a recent survey indicates that this demand is about to level out (Xylia and Silveira, 2017). To expand, it is necessary to invest in both production and distribution. In 2017, Gasum - a large Finnish utility with a focus on natural gas - acquired a Swedish biogas producer with several existing plants. A year later, supported by investment grants from the Swedish Environmental Agency, they announced plans for the rapid establishment of an extensive LNG (liquid natural gas) distribution network in the Nordic countries, targeting long-haulage trucks. In a press release, Gasum argued that the substitution of diesel with LNG would result in reduced pollutants, greenhouse gases, and noise. Moreover, they argued that the establishment of an LNG distribution network could facilitate a future substitution to LBG (liquid biogas), potentially reducing greenhouse gas emissions even further (Gasum, 2018).

There is no national price for biogas in Sweden; actors negotiate and calculate prices differently in different market segments. For car owners, the biogas price follows the global price of gasoline and the price for haulers will likely follow the diesel price. In the case of buses, the operators negotiate long-term contracts with biogas distributors, and industrial users will probably adopt similar pricing models. Table 1 presents a compilation of the current and targeted market segments, describing their user profiles and listing the specific related investments. Whereas biogas production and upgrading facilities are necessary for all segments, there are significant differences between the segments regarding the required investments in distribution systems to make biogas accessible and thus tradable, as well as in equipment to facilitate use.

Table 1. Current and targeted market segments for biogas in Sweden.

\begin{tabular}{|c|c|c|}
\hline Market segment & User profile & Specific investments \\
\hline Buses (current) & Bus operators & $\begin{array}{l}\text { Local CBG distribution networks, bus depot filling } \\
\text { stations, CBG/CNG buses }\end{array}$ \\
\hline Cars (current) & $\begin{array}{l}\text { Taxi operators, } \\
\text { municipalities, } \\
\text { companies, consumers }\end{array}$ & $\begin{array}{l}\text { Local and national CBG/CNG distribution networks, } \\
\text { public } C B G / C N G \text { filling stations, } C B G / C N G \text { cars }\end{array}$ \\
\hline $\begin{array}{l}\text { Light trucks and } \\
\text { refuse trucks } \\
\text { (current) }\end{array}$ & $\begin{array}{l}\text { Municipalities, } \\
\text { companies }\end{array}$ & $\begin{array}{l}\text { Local CBG distribution networks, public and/or } \\
\text { non-public filling stations, CBG/CNG trucks }\end{array}$ \\
\hline $\begin{array}{l}\text { Long-haulage } \\
\text { trucks (targeted) }\end{array}$ & Haulers & $\begin{array}{l}\text { Liquefaction facilities, national LBG/LNG } \\
\text { distribution network, public LBG/LNG filling } \\
\text { stations, LBG/LNG trucks }\end{array}$ \\
\hline Industry (targeted) & Manufacturing firms & $\begin{array}{l}\text { Liquefaction facilities, LBG/LNG distribution } \\
\text { networks, LBG storage, manufacturing equipment }\end{array}$ \\
\hline
\end{tabular}

With public transport authorities demanding biogas buses, bus operators who have won contracts have had to invest in such vehicles and make deals with biogas distributors on fuel deliveries. The buses have ensured stable demand and a high degree of capacity utilization, 
which has made it easier for biogas producers and distributors to justify investments in production facilities and local distribution systems. Cars represent a potentially larger but more disparate market segment in which two specific niches have been important: municipal service cars and taxis. Both predominantly operate in local areas. Similarly, municipalities have used biogas-fueled light trucks and refuse trucks, which also operate in local areas. In terms of investments in local distribution networks, these niches have benefitted from synergies with the bus segment.

Extending beyond the local niches requires more elaborate distribution networks. However, the capacity utilization has been much lower for public filling stations than for filling stations at bus depots, and when reaching out to private users, biogas cannot obtain advantages through public procurement. Production and distribution of LBG may open new segments; however, since the users in the long-haulage truck and industrial segments are professional private buyers, they are more likely to carefully assess competing alternatives. They may attach some value to environmental performance in their judgments. However, even in those cases, renewable fuel alternatives that conform better to existing fuel distribution systems, vehicles, and/or manufacturing equipment may be favored over biogas. Hence, biogas needs specific policy support to compete in these segments.

\subsection{Proving the system}

The primary technology for producing biogas is anaerobic digestion of organic substrates. Since the mid-20th century, Swedish sewage plants have used anaerobic digestion to reduce sludge volume and odor and to eliminate infectious matter in wastewater. Moreover, waste management companies have collected biogas from spontaneous digestion of organic wastes at landfill sites, with the intention of reducing methane leakage. Until the mid-1990s, biogas was considered a by-product that had little or no value. Plants primarily used it internally to generate process heat, or simply removed it by flaring.

In the early 1990s, however, pioneering Swedish cities started developing systems for biogas production and upgrading with the intention of facilitating use of biogas for inner-city buses. They expanded existing production capacity at sewage treatment plants by means of codigestion facilities, using organic waste from households and food industry. The prime justification for this was local environmental problems related to waste management and poor inner-city air quality due to diesel exhausts from buses. Moreover, it was possible to use residual digestates from co-digestion plants as fertilizers in local agriculture. Thus, several Swedish municipalities took the initiative to develop, build and operate production and upgrading facilities, as well as local gas distribution networks (Appendix 2 presents data on Swedish biogas production and distribution).

In a retrospective analysis of one of the pioneering cities, Fallde and Eklund (2015) showed how the early experimental activities transformed into a mature local system, which has served as a role model for the building of biogas systems in several other cities. The system development depended on close interaction between the municipal energy and waste management utility, playing a critical role as a systems builder, and the public transport 
authority, promoting biogas use. ${ }^{1}$ The long-term contract-bound public transport operations have ensured stable demand and have also nurtured ambitions to grow and expand to new market segments.

Biogas producers and distributors have particularly targeted cars, although penetrating the car segment has proved to be difficult. Figure 2 presents the share of vehicles fueled by compressed biogas (CBG) or compressed natural gas (CNG) in Sweden based on registration statistics. The data shows that cars have reached a share of about 1 percent, compared to 18 percent for buses. ${ }^{2}$ Low sales volumes have made car manufacturers reluctant to supply CNG/CBG-fueled models. Furthermore, there have been incidents of exploding gas tanks, which have challenged public opinion of biogas as a functioning and safe fuel. In March 2019, for example, a biogas bus exploded in Stockholm city due to a collision with a roadblock, causing a massive fire and injuries to the driver (fortunately the bus did not have any passengers at the time). One of our respondents at an energy utility recalled: "I took a taxi in Stockholm and the first thing the driver says when he hears me talking about biogas is 'I don't want to drive on that shit fuel' because he had a gas car and he had experienced multiple problems”. In addition to problems associated with exploding tanks and engine problems, empty filling stations have been a serious problem, making it difficult at times to get biogas.

\footnotetext{
${ }^{1}$ Fallde and Eklund's analysis shows that besides engaging in technical development in biogas production, distribution systems and gas-fuelled vehicles, the utility devoted substantial efforts to obtain and maintain support from the municipal board. This required repeated requalification, framing of biogas as a plausible solution to urgent problems that were present on the local political agenda. Moreover, the analysis shows how biogas was a central part of the public transport authority's campaign to improve the environmental profile of the local public transport.

${ }^{2}$ The registration statistics include all types of buses. According to Magnusson and Berggren (2018), penetration in public transport city buses is above $30 \%$.
} 


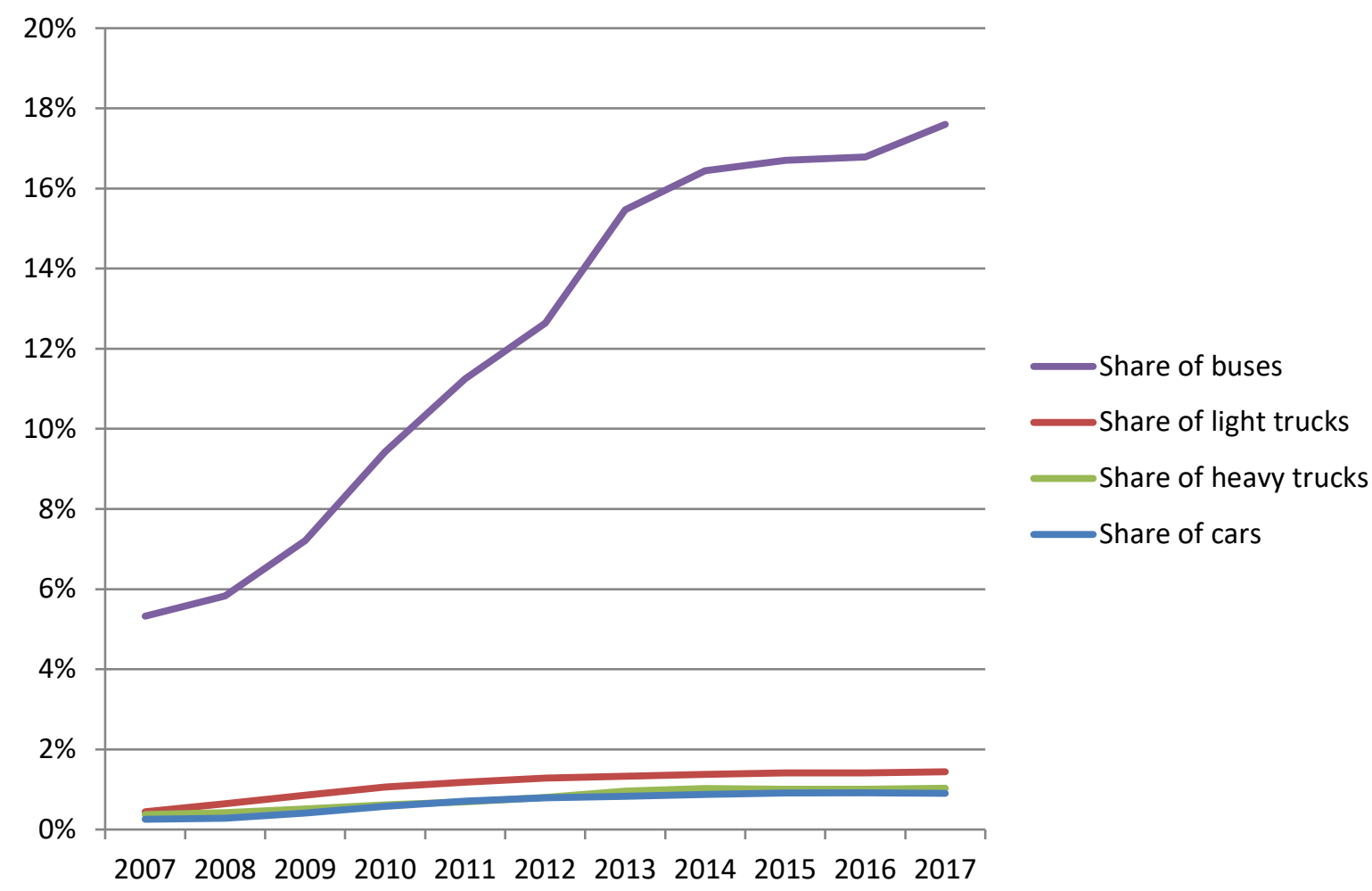

Figure 2. Share of CBG/CNG-fueled vehicles in Sweden, 2007-2017. Source: Trafikanalys, 2018.

Trucks are another targeted market segment. The registration statistics in Figure 2 indicate a share like that for cars. However, in recent years, the two Swedish truck producers, Volvo and Scania, have developed and released heavy trucks with engines and tanks for liquid natural gas (LNG) or biogas (LBG). By cooling the gas so it condenses into liquid form, the energy density becomes higher, which means that vehicles do not require bulky compression tanks. This makes it possible to use the gas for long-haulage operations and it could also open possibilities for manufacturing firms to substitute fossil gas in industrial processes. In Sweden, one LBG demonstration plant has operated since 2011. In 2018, two Swedish biogas producers announced plans to build additional plants.

The new truck models from Volvo and Scania have sparked enthusiasm among Swedish biogas advocates. However, an environmental manager at Volvo Trucks confessed in an interview that although they have validated the ability of trucks to operate on LBG, LNG would be the primary fuel due to a lack of LBG. Referring to the two models they have released, the manager stated that “... unfortunately, from an environmental perspective, these two new trucks will run on natural gas”. A consultancy report assessed that long-haul trucks would be able to use approximately 4 TWh LNG/LBG by 2030 in Sweden (Larsson and Wallmark, 2016). By comparison, the total Swedish biogas production in 2017 was 2.1 TWh, of which 1.3 TWh was upgraded. Hence, to realize the transition to LBG for long-haulage trucks, significant production capacity additions will be required, and large production units will be preferred to allow for upgrading and liquefaction. Inventories of available substrates suggest that the national annual potential for biogas through digestion of organic waste, wastewater, and manure is approximately 6.2 TWh. By using energy crops in accordance 
with EU restrictions on land use, it is possible to increase this to about 7 TWh (Börjesson, 2016; Swedish Gas Association, 2018).

Researchers, biogas technology firms, and biogas producers are constantly searching for new solutions to increase the yield from biogas production plants. Increased production through co-digestion is difficult since the producers have already picked many of the low-hanging fruits; namely, the use of organic waste from households and the food industry. This means that it is necessary to experiment with lower-grade organic material. This causes problems because organic waste from public spaces and restaurants, for example, is often mixed with non-digestible material such as metal and plastics. In many cases, the producers have had to check and sort the incoming material manually. The inadequate quality of the collected waste has also caused problems for farmers who use the digestates as fertilizers. Problems with remaining pieces of plastics and metals has forced biogas technology firms to find technical solutions. Moreover, given that anaerobic digestion is a biological process, combining different types of organic substrates is complicated. Altering the substrate mix increases the risk of production problems. Thus, process validation is difficult and there have been frequent production disruptions, which has had negative effects on the producers' credibility. Figure 3 shows a picture of mixed substrates at a co-digestion plant.

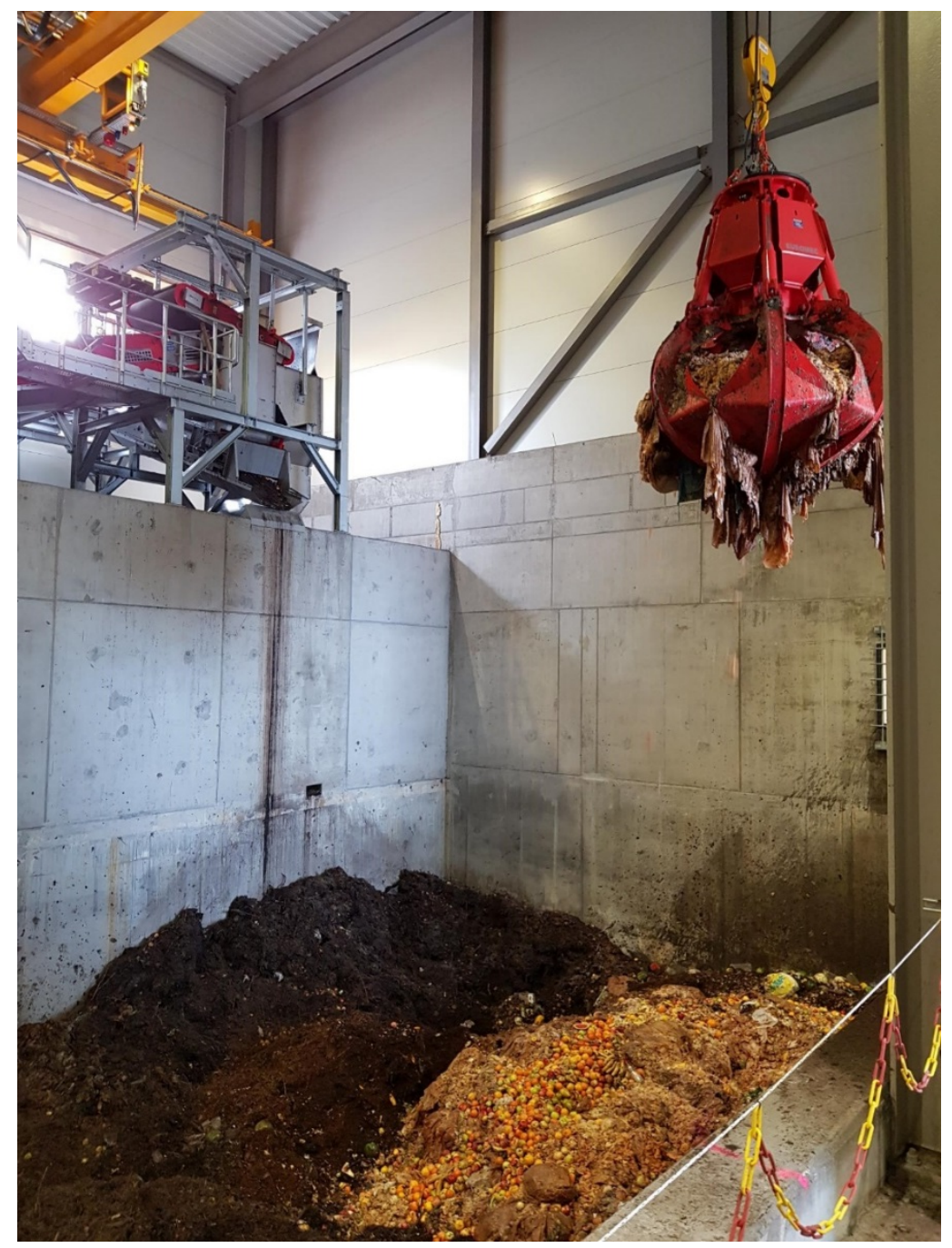

Figure 3. Photograph of mixed organic wastes at a co-digestion plant. Source: Authors. 
Sweden has a large forest industry and there is a significant potential to increase the national biogas production capacity by means of thermal gasification of forest residues (Lönnqvist et al, 2017). However, thermal gasification is a different process to digestion; it does not solve any local waste management problems and it does not deliver any biofertilizers for organic farming. Sweden's only gasification facility is Gobigas in Gothenburg, described in section 4.1. The municipal energy utility company Göteborg Energi built Gobigas as a demonstration plant with the intention of validating process technologies developed at the local technical university. Gobigas, however met fierce criticism from the local media. Even though Göteborg Energi could validate the technical functionality, the facility turned out to be a commercial failure. The media focused its criticism on the financial risk exposure, arguing that municipalities should not let local citizens pay for large projects with uncertain outcomes. In 2017, Göteborg Energi announced its intention to sell Gobigas, but a year later it had still not found a suitable buyer and announced that the operations would cease.

\subsection{Constructing the narrative}

Following the establishment of local production and use, Swedish biogas producers have framed the dominant narrative around local circular flows. This narrative describes a city in which citizens sort their own organic waste, which refuse trucks collect and transport to the biogas plant. The biogas plant turns the waste into renewable fuel for buses, serving the citizens. Municipalities have created informal contracts with citizens through promotional campaigns, envisioning biogas as an important part of a resource-efficient, recyclingoriented, and sustainable society. In the city of Uppsala, employees from the municipalityowned biogas producer visited families in their homes to inform them about the benefits of collecting organic household wastes. One respondent working as a business developer at a regional biogas advocacy coalition ${ }^{3}$ argued: “... it is my waste that is collected, and the benefits come back to me, it is the notion of symbiosis". This notion motivates citizens to sort their organic wastes and it justifies public engagement to develop and implement systems for organic waste collection and sorting, as well as biogas production and use. Thus, municipalities put considerable effort into constructing and maintaining a norm within the local community that biogas is something good and worth supporting. Figure 4 illustrates this, showing a promotional picture used by a municipal utility from one of the pioneering cities. The picture depicts citizens as co-creators of value, being active both on the supply side (sorting organic wastes in green bags) and on the demand side (using biogas-fueled buses).

\footnotetext{
${ }^{3}$ Regional biogas advocacy coalitions operate in different geographical areas (Biogas West, Biogas East, Biogas South, Biogas Southeast). They bring together municipalities, producers, distributors, researchers, and other stakeholders, informing about the benefits of biogas, visualising biogas systems, coordinating activities to develop biogas systems, and promoting increased biogas production and use.
} 

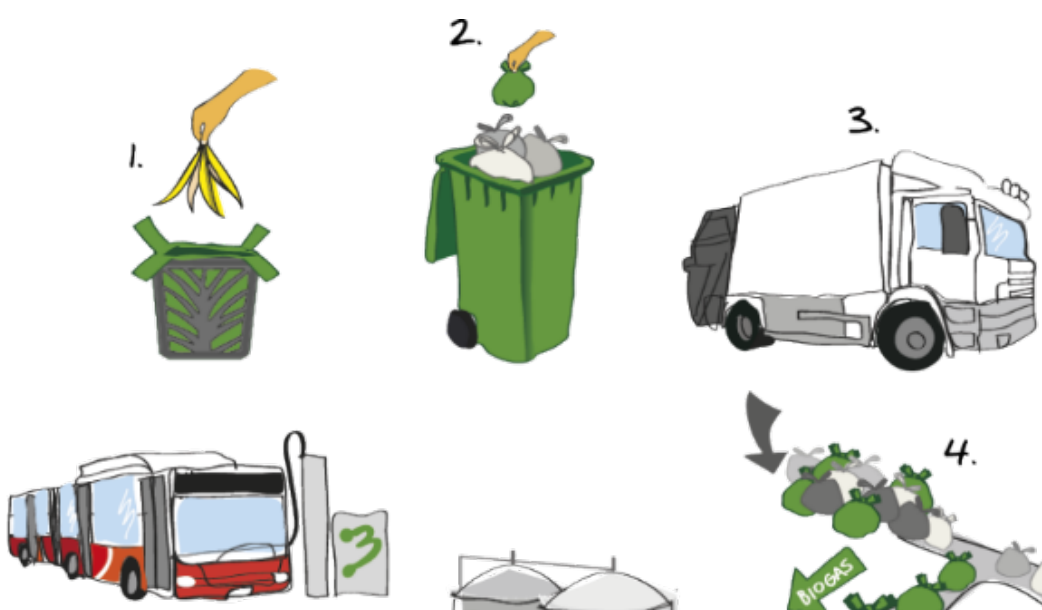

6.
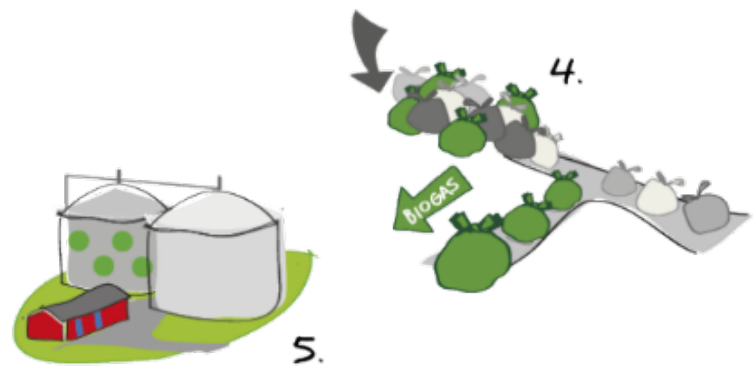

5 .

Figure 4. Promotional picture for biogas from the municipal utility Tekniska Verken $i$ Linköping $A B$ (reprinted with permission).

This local circular narrative unifies a wide variety of biogas advocates, from producers, distributors, and public transport authorities to politicians, public servants, and researchers. The narrative has evolved from its initial focus on waste management and local air quality to incorporate additional environmental issues that have become increasingly important in sociopolitical debates, including organic agriculture and global warming. One respondent at an energy utility went as far as to state that biogas is “... the essence and symbol, and most important pawn in the circular economy". Figure 5 shows a promotional picture from the Federation of Swedish Farmers that illustrates their vision of farm-based biogas production, using manure as a substrate (“Gårdsbaserad biogas”). The picture translates farming-related objects into the narrative, putting circular flows ("kretslopp") at the center. It also adds new business opportunities ("nya affärsområden”) and energy security (“energitrygghet”) to the alleged benefits of biogas. 


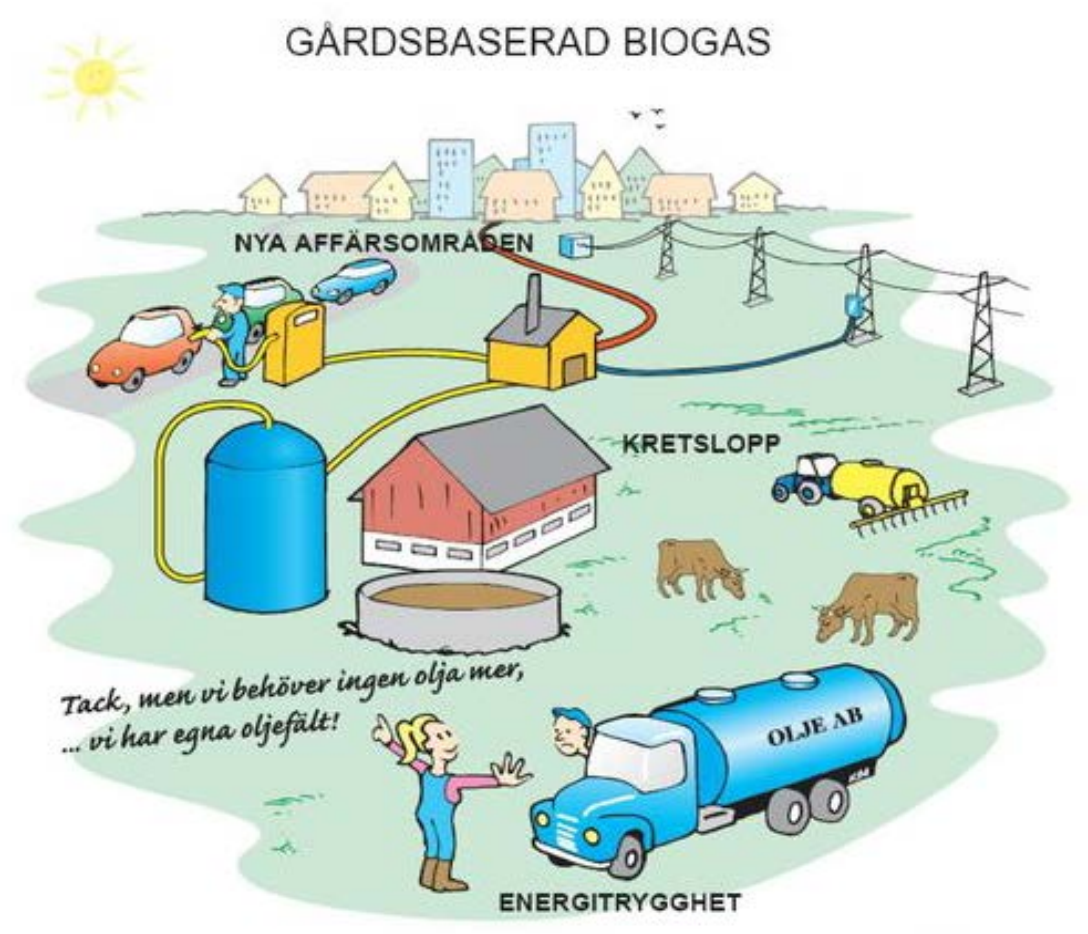

Figure 5. Promotional picture from the Federation of Swedish Farmers. The farmer is saying to the oil truck driver: "Thanks, but we do not need oil anymore, we have our own oil fields!" (Reprinted with permission).

To qualify biogas as a competitive product, it is important to rule out competing technologies. The local circular narrative, with its references to multiple societal and environmental benefits, is important in this respect. Advocates promote biogas not only by ruling out fossil fuels, but also by ruling out alternative waste management technologies: "As biogas solutions contribute waste treatment, energy supply and nutrients in one process, it is hard for technologies like aerobic wastewater treatments, incineration or composting to compete. They only contribute one aspect each” (Hagman and Eklund, 2016, p. 26). Moreover, advocates use the narrative to rule out other new energy and transport alternatives: "The government has proposed a particular subsidy scheme to increase the use of electric buses. This subsidy scheme ought to include gas-fueled buses since they not only contribute to a better climate and cleaner air in the cities, but also contribute to a closed circular flow” (Swedish Gas Association, 2015, p. 13-14.)

The local circular narrative suggests that biogas is much more than a renewable fuel, proposing several different product qualifications. According to the rhetoric, biogas can help solve virtually all sustainability problems associated with today's society. A research report distributed by the advocacy coalition Biogas East states that biogas produced by digestion “... can contribute to all of the 17 UN Sustainable Development Goals” (Hagman and Eklund 2016, p. 26). The local circular narrative is visual and comprehensible, pointing towards multiple benefits through symbiotic relationships between different categories of actors. Thus, the story and the translations are very useful when lobbying for public support. The 
Swedish Gas Association ${ }^{4}$ has used this narrative to promote substantial growth in national biogas production, from 2.1 TWh in 2017 to 15 TWh by 2030 (Swedish Gas Association, 2015, 2018). Their prime agenda is to substitute fossil fuels in transport, which would reduce the likelihood of cannibalizing the gas incumbents' existing markets. ${ }^{5} 80$ percent of the 15 TWh biogas is supposed to be used as vehicle fuel. Referring to national ambitions to make the transport system independent from fossil fuels, the Swedish Gas Association has proposed several interventions from the Swedish Government and its agencies in support of biogas. The propositions include long-term and stable biogas subsidy schemes, harmonization with other European countries, mandatory requirements for collection of organic waste from households and businesses, and special support for investments in large-scale thermal gasification facilities.

The Swedish Gas Association has collaborated with both public and private actors to develop this proposed national biogas strategy. ${ }^{6}$ Figure 6 shows an image from the strategy document, an elaborated version of the local circular narrative, which includes farmers' use of biofertilizers to produce organic food and describes biogas as an integrated part of citizens' daily lives. The image shows possibilities for using biogas in a broad range of applications, thus envisioning significant growth opportunities. The addition of an LNG freight ship adds fossil natural gas to the narrative, translating the biogas system to gas incumbents' existing business practices. Apart from environmental benefits, the strategy document suggests that biogas will lead to possibilities for employment, export, and economic prosperity.

\footnotetext{
${ }^{4}$ The Swedish Gas Association (Energigas Sverige) is the gas industry association in Sweden and is also the most prominent national advocate for biogas. This is a member-funded network, dedicated to promoting the use of different types of gas, including biogas, natural gas, hydrogen, and liquefied petroleum gas (LPG).

${ }^{5}$ In 2017, the use of natural gas in Sweden was 12.1 TWh, approximately two-thirds of which was used in industrial processes (Swedish Gas Association, 2019).

${ }^{6}$ Except for the Swedish Gas Association, the following actors have contributed to the proposed strategy: the Swedish Waste Management Association (industry association), Gasnätet i Stockholm AB (owner/operator of the local gas grid in Stockholm), Scandinavian Biogas (biogas producer), Biogasbolaget (biogas producer), Göteborg Energi (municipal energy utility), SSAB (steel manufacturer), Svensk Biogas (biogas distributor), Purac (biogas technology firm), Swedegas (owner/operator of gas transmission pipeline), Eon (energy utility), Region Skåne (regional public authority), and Öresundskraft (municipal energy utility).
} 


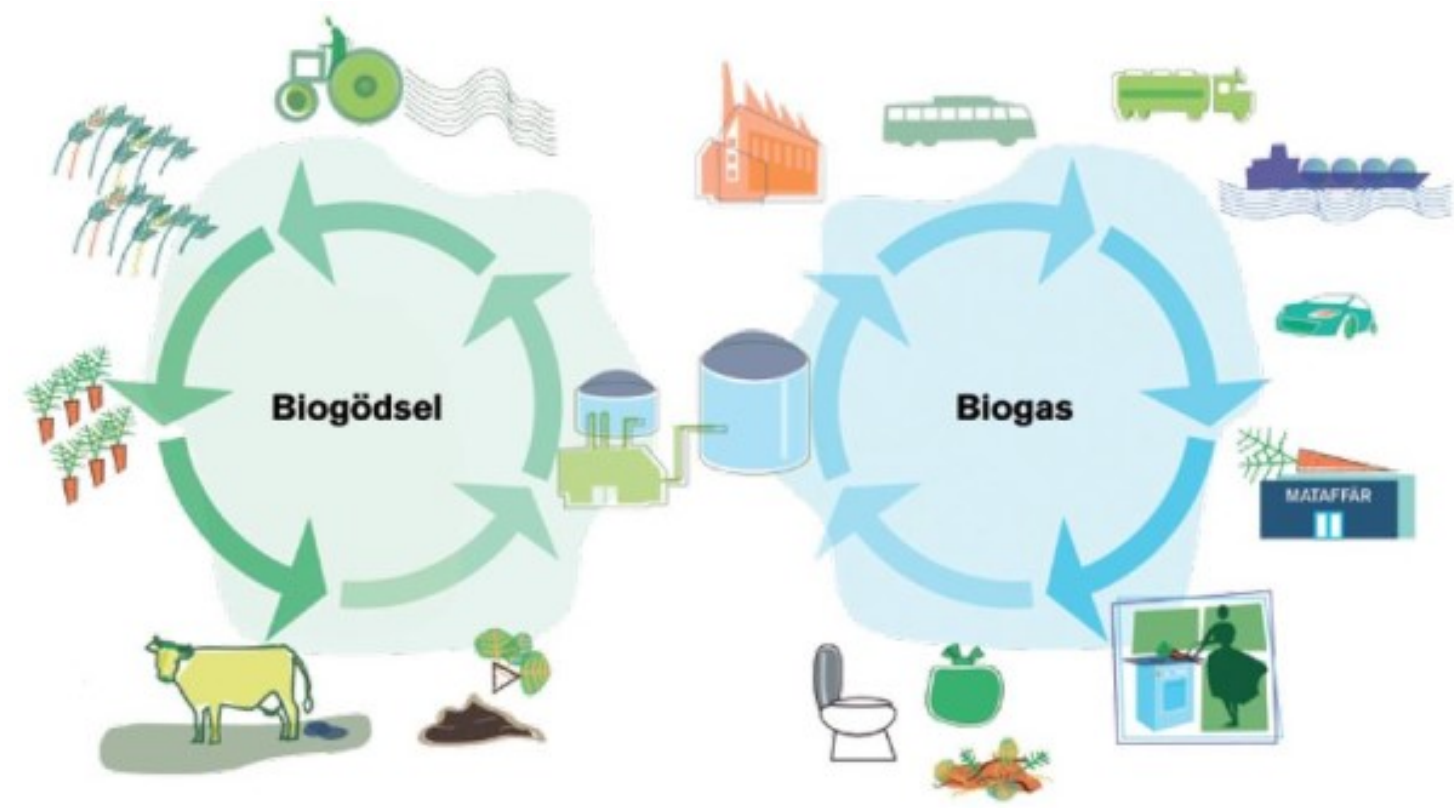

Figure 6. Image from the proposed national biogas strategy (biogödsel=biofertilizer, reprinted with permission from the Swedish Gas Association).

\section{Discussion}

The case analysis shows how key actors have engaged in various biogas market-shaping activities in Sweden. Table 2 summarizes the analysis of the three processes outlined in the previous section, presenting key actor categories and key activities in the market-shaping processes.

Table 2. Key activities and key actor categories in Swedish biogas market-shaping processes.

\begin{tabular}{|c|c|c|c|c|c|c|c|c|c|c|c|c|c|c|c|}
\hline & \multicolumn{14}{|c|}{ Type of actors } \\
\hline & & \multicolumn{3}{|c|}{ Public } & \multicolumn{8}{|c|}{ Private } & \multicolumn{3}{|c|}{$\begin{array}{l}\text { Public \& } \\
\text { private }\end{array}$} \\
\hline Processes & Activities & 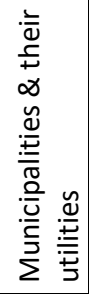 & 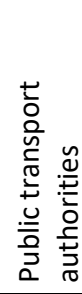 & 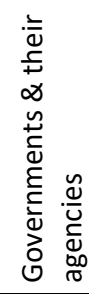 & 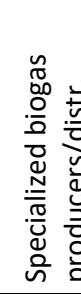 & 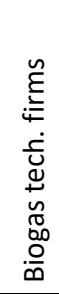 & 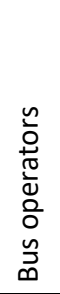 & 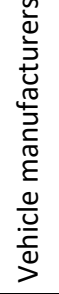 & 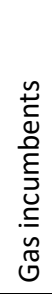 & 峁 & 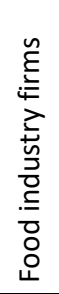 & 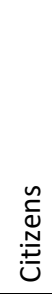 & 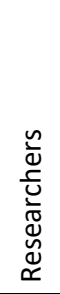 & 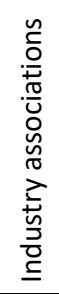 & 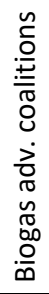 \\
\hline \multirow{5}{*}{$\begin{array}{l}\text { Enabling } \\
\text { exchange } \\
\text { practices }\end{array}$} & Demanding & & & & & & & & & & & & & & \\
\hline & Supplying & & & & & & & & & & & & & & \\
\hline & Negotiating & & & & & & & & & & & & & & \\
\hline & Investing & & & & & & & & & & & & & & \\
\hline & Subsidizing & & & & & & & & & & & & & & \\
\hline \multirow{3}{*}{$\begin{array}{l}\text { Proving the } \\
\text { system }\end{array}$} & Experimenting & & & & & & & & & & & & & & \\
\hline & Validating & & & & & & & & & & & & & & \\
\hline & System-building & & & & & & & & & & & & & & \\
\hline
\end{tabular}




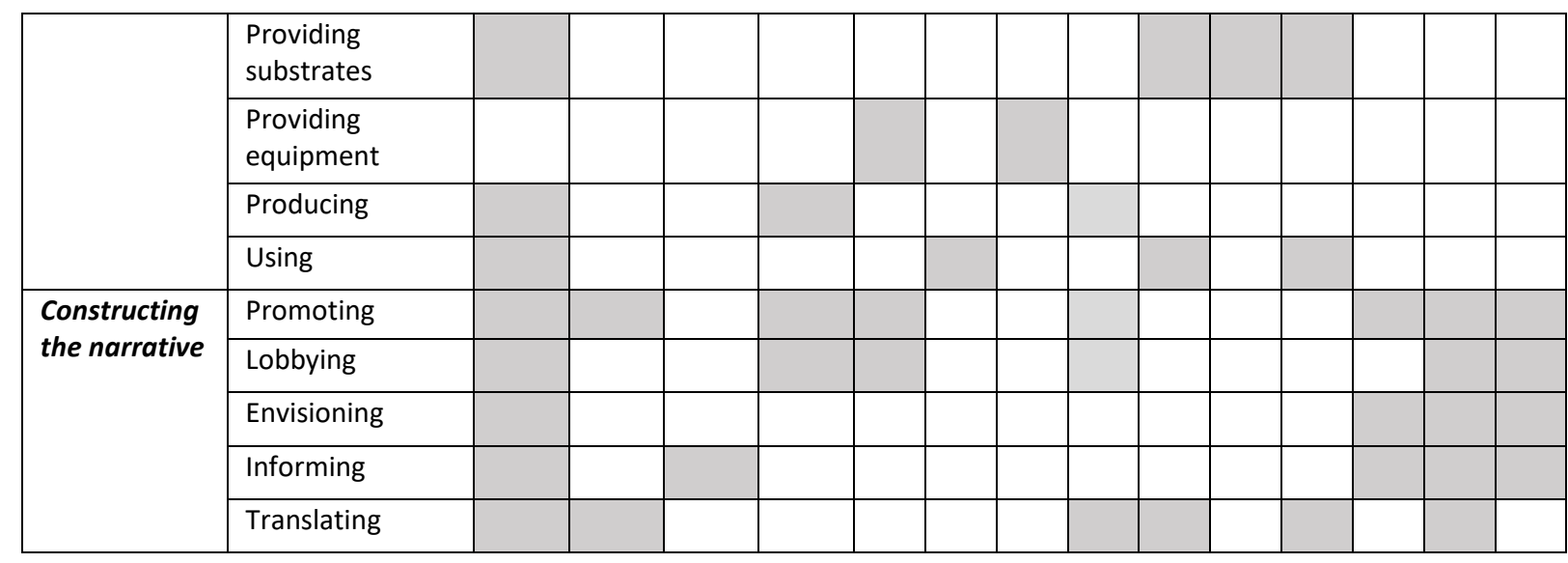

The Swedish biogas system has primarily demonstrated its value locally and actors that attach substantial value to local benefits have assumed key roles in system-proving activities. Municipalities have acted as both producers and users, assigning the critical system-building role to their utilities. However, the demand has primarily been shaped by another group of actors: public transport authorities. As municipal utilities collaborated with public transport authorities to develop local biogas system solutions, they engaged in exchange practices, demanding and supplying biogas to create value in local niches. In those niches, the traded value of biogas was wider than just the cost and revenue dimensions. This wider contextual value was based on all societal and environmental benefits that biogas brought to the local society, such as cleaner air, local business opportunities, reduced waste management costs for local companies, and organic fertilizers for local farmers. Governmental investment grants and internationally negotiated subsidies eventually assisted the exchanges. These interventions made judgments easier for investors and buyers, and they attracted private firms to play a more active part in the market-shaping.

Nevertheless, problems have occurred repeatedly, resulting in questions about whether biogas is a sound product and urging municipal utilities as well as private producers/distributors to prove the value of the biogas system. Thus, technical experimentation and validation activities have been critical and recurrent. Researchers and equipment providers (biogas technology firms and vehicle manufacturers) have assisted these activities. Moreover, the system-proving has depended on inputs from food industry firms, farmers and citizens, acting as substrate providers. Farmers have used by-products from biogas production for organic farming and gas incumbents have taken a leading role in the biogas distribution, which has translated biogas into opportunities for them to expand existing businesses and compete on new markets.

Through their narration of the local circular system, Swedish biogas advocates have constructed a shared identity that has served as a foundation for dedicated advocacy coalitions. Several actors have been involved in this, including municipalities and their utilities, public transport authorities, specialized biogas producers and distributors, biogas technology firms, and researchers. Objects such as bags for organic household waste collection and biogas-fueled buses have made the narrative tangible for local citizens, whose engagement has been critical to facilitate organic waste collection from households. 
The local circular narrative remains one of the most valuable assets of the Swedish biogas advocates. It differentiates biogas, not only from the existing fossil-based regime, but also from other renewable alternatives. This has attracted attention from established industry associations, including the Federation of Swedish Farmers and the Swedish Gas Association, translating the narrative to serve the purposes of their members. Promoting biogas as a system that provides multiple environmental and societal benefits has made it possible to lobby for governmental support and call for institutional reforms. However, in order to realize expectations of extensive growth, it will be necessary to experiment with new substrates, new process technologies and new system configurations. Thus, growth aspirations call for market-shaping processes that will challenge the current system. Hence, Swedish biogas advocates find themselves referring to the differentiating attributes of a prominent narrative in their promotion of socio-technical system alterations that contradict it. Under such circumstances it is questionable to what extent the narrative can stimulate growth - and, indeed, if it will survive growth.

Arguably, municipalities and their utilities have been key actors in Swedish biogas marketshaping; however, increased size of production units means increased risk exposure, and public opinion has started to question whether such risks are congruent with the institutionalized practice of municipalities. This creates opportunities for other actors to assume key roles as investors, system builders, and advocates. While internationally operating gas incumbents have shown such ambitions, the local anchoring of these firms is limited, and they rely on synergies with large-scale businesses in fossil fuels to obtain return on their investments. In that sense, the cost, revenue and price dimensions are becoming more important for the biogas market-shaping than the local contextual value.

\section{Conclusions}

By merging recent market-shaping research with findings from sustainability transition studies, this paper contributes a framework for the shaping of sustainable markets. The framework consists of market-shaping processes built up by market actors' activities and inter-related by their respective value outputs. Based on a definition of markets as valuecreating structures, we propose enabling exchange practices, proving the system and constructing the narrative as three critical market-shaping processes. Our framework suggests that different kinds of value constitute critical outputs from, and inputs to, these processes. Demonstrated value, which is an output of system-proving, makes the narrative comprehensible and plausible. Expected value is an output of narrative construction that makes it possible to justify investments. Traded value is an output of exchange practices that provides monetary resources necessary for building and operating systems. Conversely, demonstrated value is a prerequisite for the exchange of resources, traded value empowers the narrative construction, and expected value provides direction for system development. Value may flow in both directions. The value flows and market-shaping processes illustrated through our case analysis show similarities with a 'reconfiguration pathway' (Geels et al., 2016; Geels and Schot, 2007; McMeekin et al., 2019), in which symbiotic innovations that solve local problems initiate processes of socio-technical restructuring. The analysis points to the recursive nature of such processes. 
Our analysis has elucidated complex processes and context-bound activities that describe a market in its making. It has shown that to obtain and sustain support, it is necessary to provide evidence recurrently, which demonstrates the value of the technology. Even in cases of relatively mature socio-technical systems, growth and aspirations of growth result in troubleshooting, bottlenecks, and structural tensions to which actors must react. Thus, it may be more fruitful to consider system proving as a continuous market-shaping process rather than an early formative stage in socio-technical system evolution (cf. Jacobsson and Bergek, 2004; Haley, 2018).

Building on contributions from previous analyses by Kern et al. (2014; 2015), our analysis has also highlighted the construction of a narrative as an important market-shaping process. More specifically, our case analysis points towards critical tensions between an established narrative and an envisioned system growth. This suggests that the legitimacy of a growing socio-technical system will be judged not only against established institutions in the surrounding society (cf. Bergek et al., 2008a/b; Markard et al., 2016), but also against the narratives that advocates use to justify system growth.

The case analysis shows that governments can compensate for insufficient access to riskwilling capital, which lends support to Mazzucato's thesis that national states can act to shape markets through their investment policies (Mazzucato, 2013; Mazzucato, 2016; Mazzucato and Semieniuk, 2017). However, our analysis also points towards several additional and equally important market-shaping activities that governments may engage in. This includes market-directed subsidizing and transnational negotiation to enable exchange practices. By expanding the discussion to the role of the public sector in the shaping of markets, our analysis illustrates how local public actors can engage in a large variety of activities. In our case, municipalities and public transport authorities have been particularly active, taking important roles as system builders, advocates, investors, producers, distributors, and users. They have also joined forces with private firms and associations to influence institutions on various levels, from the local society to the national government and the European Commission. Hence, they have been highly involved in what Beck (1997) referred to as subpolitics; that is, forms of politics outside and beyond the representative institutions of the political system.

The research presented in this paper has outlined and illustrated a framework consisting of three market-shaping processes. The framework describes these processes as equally important. A logical extension of this research is to investigate and explain differences in the relative importance of the processes in various cases and contexts. Future comparative analyses, involving different technologies, countries and institutional settings, may be useful for this purpose. Such analyses may also investigate generic and context-specific activities that build the market-shaping processes.

\section{Acknowledgements}

The article is based on research conducted in the Biogas Research Center (BRC), which is supported by the Swedish Energy Agency, Linköping University and industrial partners. The authors further acknowledge the financial support of Riksbankens Jubileumsfond (The Swedish Foundation for Humanities and Social Sciences) (research grant number: P18-0588- 
1). We are grateful for constructive comments on draft manuscripts provided by Daniel Kindström, three anonymous reviewers and the Associate Editor. 


\section{References}

Ahrne, G., P. Aspers and N. Brunsson (2015). The Organization of Markets. Organization Studies 36(1), 7-27.

Azimont, F., and Araujo, L. (2007). Category reviews as market-shaping events. Industrial Marketing Management, 36(7), 849-860.

Bauer, F. (2018). Narratives of biorefinery innovation for the bioeconomy - Conflict, consensus, or confusion? Environmental Innovation and Societal Transitions, 28, 96-107.

Beck, U. (1997). The Reinvention of Politics: Rethinking Modernity in the Global Social Order. Cambridge: Polity Press.

Bergek, A., Jacobsson, S., and Sandén, B. A. (2008b). 'Legitimation’ and ‘development of positive externalities': two key processes in the formation phase of technological innovation systems. Technology Analysis and Strategic Management, 20(5): 575-592.

Bergek, A., Jacobsson, S., Carlsson, B., Lindmark, S. and Rickne, A. (2008a). Analyzing the functional dynamics of technological innovation systems: A scheme of analysis. Research Policy, 37(3): 407-429.

Berggren, C. Magnusson, T. and Sushandoyo, D. (2015). Transition pathways revisited: Established firms as multi-level actors in the heavy vehicle industry. Research Policy, 44, 1017-1028.

Blanchard, B. and Fabrycky, W. J. (1990). Systems engineering and analysis: Prentice Hall, Englewood Cliffs, NJ.

Börjesson, P. (2016). Potential för ökad tillförsel och avsättning av inhemsk biomassa i en växande svensk bioekonomi. Lunds universitet Institutionen för teknik och samhälle, Avdelningen för miljö- och energisystem Rapport nr. 97

Callon, M., C. Méadel and Rabeharisoa, V. (2002). The economy of qualities. Economy and Society, 31(2), 194-217.

Cavicchi, B. (2016). Sustainability that backfires: the case of biogas in Emilia Romagna. Environmental Innovation and Societal Transitions, 21, 13-27.

Chandler, J. D. and Vargo, S. L. (2011). Contextualization and value-in-context: How context frames exchange. Marketing Theory, 11(1), 35-49.

Dewald, U. and Truffer, B. (2017). Market formation and innovation systems, in: The Elgar Companion to Innovation and Knowledge Creation, chapter 37, pp. 610-624, Edward Elgar Publishing.

Dewald, U. and Truffer, B. (2011). Market formation in technological innovation systems - diffusion of photovoltaic applications in Germany. Industry and Innovation, 18(03), 285-300.

Doganova, L. and Karnoe, P. (2015). Building markets for clean technologies: Controversies, environmental concerns and economic worth. Industrial Marketing Management, 44, 22-31.

Dubois, A and Gadde, L-E (2002). Systematic combining: an abductive approach to case research. Journal of Business Research, 55, 553-560.

EC (2017). Optimal use of biogas from waste streams: An assessment of the potential of biogas from digestion in the EU beyond 2020, European Commission.

Edvardsson, B., Kleinaltenkamp, M., Tronvoll, B., McHugh, P. and Windahl, C. (2014). Institutional logics matter when coordinating resource integration. Marketing Theory, 14(3), 291-309.

Edvardsson, B., Tronvoll, B., and Gruber, T. (2011). Expanding understanding of service exchange and value co-creation: a social construction approach. Journal of the Academy of Marketing Science, 39 (2), 327-339.

Eisenhardt, K.E. and Graebner, M.E. (2007). Theory Building From Cases: Opportunities And Challenges. Academy of Management Journal. 50, 25-32.

Fallde, M., and Eklund, M. (2015). Towards a sustainable socio-technical system of biogas for transport: the case of the city of Linköping in Sweden. Journal of Cleaner Production, 98, 17-28. 
Finch, J. H. and Acha, V. L. (2008). Making and exchanging a second-hand oil field, considered in an industrial marketing setting. Marketing Theory, 8(1), 45-66.

Gasum (2018). Tunga vägtransporter går in i gasens tidsålder: De nordiska länderna får ett nätverk med 50 tankningsstationer. https://www.gasum.com/sv/gasum/nyheter/2018/tunga-vagtransporter-gar-in-i-gasenstidsalder-de-nordiska-landerna-far-ett-natverk-med-50-tankningsstationer/, accessed 2018-10-20

Geels, F. W. (2004). From sectoral systems of innovation to socio-technical systems: Insights about dynamics and change from sociology and institutional theory. Research Policy, 33(6), 897-920.

Geels, F. W., and Schot, J. (2007). Typology of sociotechnical transition pathways. Research Policy, 36(3), 399-417.

Geels, F. W., Kern, F., Fuchs, G., Hinderer, N., Kungl, G., Mylan, J., Neukirch, M., and Wassermann, S. (2016). The enactment of socio-technical transition pathways: A reformulated typology and a comparative multi-level analysis of the German and UK low-carbon electricity transitions (1990-2014). Research Policy, 45(4), 896-913.

Haley, B. (2018). Integrating structural tensions into technological innovation systems analysis: Application to the case of transmission interconnections and renewable electricity in Nova Scotia, Canada. Research Policy, 47(6), 1147-1160.

Hagman, L. and Eklund, M. (2016). The role of biogas solutions in the circular and bio-based economy, Biogas Research Center and Biogas Öst.

Harrison, D. and Kjellberg, H. (2016). How users shape markets. Marketing Theory, 16 (4), 445-468.

Hughes, T. P. (1993). Networks of power: electrification in Western society, 1880-1930: JHU Press.

Håkansson, H., and Snehota, I. (2017). Interactivity in Business Networks: Emerald Publishing Limited.

Jacobsson, S., and Bergek, A. (2004). Transforming the energy sector: the evolution of technological systems in renewable energy technology. Industrial and Corporate Change, 13(5), 815-849.

Jaworski, B., Kohli, A. K., \& Sahay, A. (2000). Market-driven versus driving markets. Journal of the Academy of Marketing Science, 28(1), 45-54.

Karltorp, K. (2016). Challenges in mobilising financial resources for renewable energy - The cases of biomass gasification and offshore wind power. Environmental Innovation and Societal Transitions, 19, 96-110.

Kemp, R., J. Schot and Hoogma, R. (1998). Regime shifts to sustainability through processes of niche formation: The approach of strategic niche management. Technology Analysis and Strategic Management, 10(2): 175-198.

Kern, F. (2015). Engaging with the politics, agency and structures in the technological innovation systems approach. Environmental Innovation and Societal Transitions, 16, 67-69.

Kern, F., A. Smith, C. Shaw, R. Raven and Verhees, B. (2014). From laggard to leader: Explaining offshore wind developments in the UK. Energy Policy, 69, 635-646.

Kern, F., B. Verhees, R. Raven and Smith, A. (2015). Empowering sustainable niches: Comparing UK and Dutch offshore wind developments. Technological Forecasting and Social Change, 100, 344-355.

Kindström, D., Ottosson, M., and Carlborg, P. (2018). Unraveling firm-level activities for shaping markets. Industrial Marketing Management, 68, 36-45.

Kjellberg, H. and Helgesson, C.-F. (2007). On the Nature of Markets and Their Practices. Marketing Theory, $7(2), 137-162$.

Kjellberg, H., Mallard, A., Arjalies, D.-L., Aspers, P., Beljean, S., Bidet, A., and Woolgar, S. (2013). Valuation Studies? Our Collective Two Cents. Valuation Studies, 1(1), 11-30.

Kjellberg, H., F. Azimont and E. Reid (2015). Market innovation processes: Balancing stability and change. Industrial Marketing Management, 44, 4-12. 
Koskela-Huotari, K., Edvardsson, B., Jonas, J. M., Sörhammar, D. and Witell, L. (2016). Innovation in service ecosystems - Breaking, making, and maintaining institutionalized rules of resource integration. Journal of Business Research, 69(8), 2964-2971.

Köhler, J., Geels, F. W., Kern, F., Markard, J., Wieczorek, A., Alkemade, F., Avelino, F., Bergek, A., Boons, F., Fünfschilling, L., Hess, D., Holtz, G., Hyysalo, S., Jenkins, K., Kivimaa, P., Martiskainen, M., McMeekin, A., Mühlemeier, M. S., Nykvist, B., Onsongo, E., Pel, B., Raven, R., Rohracher, H., Sandén, B., Schot, J., Sovacool, B., Turnheim, B., Welch, D., and Wells, P. (2019). An agenda for sustainability transitions research: State of the art and future directions. Environmental Innovation and Societal Transitions.

Lantz, M., M. Svensson, L. Björnsson, and Börjesson, P. (2007). The prospects for an expansion of biogas systems in Sweden - Incentives, barriers and potentials. Energy Policy 35(3), 1830-1843.

Larsson, M. and C. Wallmark (2016). Scenarier för gasanvändning i transportsektorn till 2030. Sveco.

Larsson, M., S. Grönkvist, and Alvfors, P. (2016). Upgraded biogas for transport in Sweden - effects of policy instruments on production, infrastructure deployment and vehicle sales. Journal of Cleaner Production, 112, Part 5: 3774-3784.

Lauber, V. and Jacobsson, S. (2016). The politics and economics of constructing, contesting and restricting socio-political space for renewables - The German Renewable Energy Act. Environmental Innovation and Societal Transitions, 18, 147-163.

Lönnqvist, T., Grönkvist, S., and Sandberg, T. (2017). Forest-derived methane in the Swedish transport sector: A closing window? Energy Policy, 105: 440-450.

MacKenzie, D. (2009). Making things the same: Gases, emission rights and the politics of carbon markets. Accounting, Organizations and Society, 34 (3-4), 440-455.

Magnusson, T., and Berggren, C (2018). Competing innovation systems and the need for redeployment in sustainability transitions, Technological Forecasting and Social Change, 126, 217-230.

Markard, J., Hekkert, M., and Jacobsson, S. (2015). The technological innovation systems framework: Response to six criticisms. Environmental Innovation and Societal Transitions, 16, 76-86.

Markard, J., Wirth, S., and Truffer, B. (2016). Institutional dynamics and technology legitimacy - A framework and a case study on biogas technology. Research Policy 45(1), 330-344.

Mazzucato, M. (2013). The entrepreneurial state: Debunking the public vs. private myth in risk and innovation. Anthem, London.

Mazzucato, M. (2016). From market fixing to market-creating: a new framework for innovation policy. Industry and Innovation, 23(2), 140-156.

Mazzucato, M., and Semieniuk, G. (2017). Public financing of innovation: new questions. Oxford Review of Economic Policy, 33(1), 24-48.

McMeekin, A., Geels, F. W., and Hodson, M. (2019). Mapping the winds of whole system reconfiguration: Analysing low-carbon transformations across production, distribution and consumption in the UK electricity system (1990-2016). Research Policy.

Meadowcroft, J. (2011). Engaging with the politics of sustainability transitions. Environmental Innovations and Societal Transitions, 1, 70-75.

Mele, C., Pels, J., and Storbacka, K. (2015). A holistic market conceptualization. Journal of the Academy of Marketing Science, 43, 100-114.

Mortensen, H. (2018). The valuation history of Danish wind power - The ongoing struggle of a challenger technology to prove its worth to society. PhD Thesis. Aalborg University.

Muniesa, F., Millo, Y., and Callon, M. (2007). An introduction to market devices. In Callon, M., Millo, Y. and Muniesa, F. (editors), Market Devices, Oxford, Blackwell, 1-12.

Musiolik, J., and Markard, J. (2011). Creating and shaping innovation systems: Formal networks in the innovation system for stationary fuel cells in Germany. Energy Policy, 39(4), 1909-1922. 
Negro, S. O., Suurs, R. A. A., and Hekkert, M. P. (2008). The bumpy road of biomass gasification in the Netherlands: Explaining the rise and fall of an emerging innovation system. Technological Forecasting and Social Change, 75(1), 57-77.

Nenonen, S., Storbacka, K. and Windahl, C. (2019). Capabilities for market-shaping: triggering and facilitating increased value creation. Journal of the Academy of Marketing Science, 47, 617-639.

Ottosson, M. and Kindström, D. (2016). Exploring proactive niche market strategies in the steel industry: Activities and implications. Industrial Marketing Management, 55, 119-130.

Pettigrew, A. M. (1997). What is a processual analysis? Scandinavian Journal of Management, 13(4), 337-348.

Raven, R., Kern, F., Verhees, B., and Smith, A. (2016). Niche construction and empowerment through sociopolitical work. A meta-analysis of six low-carbon technology cases. Environmental Innovation and Societal Transitions, 18, 164-180.

Schot, J. and F. W. Geels (2007). Niches in evolutionary theories of technical change. Journal of Evolutionary Economics 17(5), 605-622.

Schot, J. and F. W. Geels (2008). Strategic niche management and sustainable innovation journeys: theory, findings, research agenda, and policy. Technology Analysis and Strategic Management, 20(5), 537-554.

Smith, A. (2007). Translating Sustainabilities between Green Niches and Socio-Technical Regimes. Technology Analysis \& Strategic Management, 19, 427-450.

Smith, A. and R. Raven (2012). What is protective space? Reconsidering niches in transitions to sustainability. Research Policy, 41(6), 1025-1036.

Søderberg, A.-M. (2003). Sensegiving and sensemaking in an integration process. In: Czarniawska, B. and P. Gagliardi (editors), Narratives we organize by: narrative approaches in organization studies, John Benjamins, 3-35.

Storbacka, K. and S. Nenonen (2011). Scripting markets: From value propositions to market propositions. Industrial Marketing Management, 40(2): 255-266.

Storbacka, K., \& Nenonen, S. (2012). Competitive Arena Mapping : Market Innovation Using Morphological Analysis in Business Markets Competitive Arena Mapping : Market Innovation Using Morphological. 0628.

Storbacka, K., \& Nenonen, S. (2015). Learning with the market: Facilitating market innovation. Industrial Marketing Management, 44, 73-82.

Sushandoyo, D. and Magnusson, T. (2014). Strategic niche management from a business perspective - taking cleaner vehicle technologies from prototype to series production. Journal of Cleaner Production, 74, 1726.

Swedish Gas Association (Energigas Sverige) (2015). Förslag till nationell biogasstrategi (Proposed national biogas strategy). Energigas Sverige.

Swedish Gas Association (Energigas Sverige) (2018). Förslag till nationell biogasstrategi 2.0 (Proposed national biogas strategy 2.0). Energigas Sverige.

Swedish Gas Association (Energigas Sverige) (2019). http://www.energigas.se/fakta-om-gas/naturgas/statistikom-naturgas/, accessed 2019-06-20

Ulkuniemi, P., L. Araujo and Tähtinen, J. (2015). Purchasing as market-shaping: The case of component-based software engineering. Industrial Marketing Management, 44, 54-62.

Van De Ven, A. H., and Johnson, P. E. (2006). Knowledge for theory and practice, Academy of Management Review, 31(4), 802-821.

Vargo, S. L., and Lusch, R. F. (2004). Evolving to a new dominant logic for marketing. Journal of Marketing, 68(1): 1-17.

Vargo, S. L., Wieland, H. and Akaka, M. A. (2015). Innovation through institutionalization: A service ecosystems perspective. Industrial Marketing Management, 44, 63-72. 
Wells, P.E. and Nieuwenhuis, P. (2017). Operationalizing Deep Structural Sustainability in Business: Longitudinal Immersion as Extensive Engaged Scholarship. British Journal of Management, 28, 45-63.

Wirth, S., Markard, J., Truffer, B., and Rohracher, H. (2013). Informal institutions matter: Professional culture and the development of biogas technology. Environmental Innovation and Societal Transitions, 8, $20-41$.

Xylia, M., and Silveira, S. (2017). On the road to fossil-free public transport: The case of Swedish bus fleets. Energy Policy, 100, 397-412. 


\section{Appendix 1 - data sources}

Table 1. Workshops, presentations, study visits and seminars attended.

\section{Participating actor categories:}
A. Municipalities and their utilities
B. Public transport authorities
C. Government and their agencies
D. Specialized biogas producers/distributors
E. Biogas technology firms
F. Vehicle manufactures
G. Gas incumbents
H. Farmers
I. Food industry firms
J. Researchers
$K$. Industry associations
L. Biogas advocacy coalitions

\begin{tabular}{|c|c|c|c|c|c|}
\hline Title/Topic of event & Organizer & Location & Dates & Participants & $\begin{array}{l}\text { Role of } \\
\text { authors }\end{array}$ \\
\hline $\begin{array}{l}\text { Biogas Research Center } \\
\text { research communication and } \\
\text { dissemination - half-year } \\
\text { seminar series with biogas } \\
\text { stakeholders }\end{array}$ & $\begin{array}{l}\text { Biogas Research } \\
\text { Center }\end{array}$ & Linköping & $\begin{array}{l}2015-05-28 / 29 \\
2015-12-03 / 04 \\
2016-05-26 / 27 \\
2016-12-01 / 02 \\
2017-11-30 / 12-01 \\
2018-05-17 / 18 \\
2018-11-29 / 30 \\
2019-05-23 / 24\end{array}$ & $\begin{array}{l}\text { A, B, C, D, E, G, } \\
J, K\end{array}$ & $\begin{array}{l}\text { Discussion- } \\
\text { panel } \\
\text { member, } \\
\text { presenter, } \\
\text { audience, } \\
\text { discussion } \\
\text { member, } \\
\text { round-table } \\
\text { discussion } \\
\text { member }\end{array}$ \\
\hline $\begin{array}{l}\text { Biogas in a regional context - } \\
\text { workshop series with invited } \\
\text { guests }\end{array}$ & $\begin{array}{l}\text { Biogas Research } \\
\text { Center }\end{array}$ & Linköping & $\begin{array}{l}2015-04-22 \\
2016-02-05 \\
2016-09-16 \\
2016-12-02\end{array}$ & $A, B, D, J, L$ & $\begin{array}{l}\text { Presenter, } \\
\text { discussion } \\
\text { member, } \\
\text { audience }\end{array}$ \\
\hline $\begin{array}{l}\text { Distribution of biogas - } \\
\text { workshop with invited guest }\end{array}$ & $\begin{array}{l}\text { Biogas Research } \\
\text { Center }\end{array}$ & Linköping & $2016-02-12$ & $E, G, J$ & $\begin{array}{l}\text { Organizer, } \\
\text { discussion } \\
\text { member }\end{array}$ \\
\hline $\begin{array}{l}\text { Biogas in the waste sector - } \\
\text { workshop with invited guests }\end{array}$ & $\begin{array}{l}\text { Biogas Research } \\
\text { Center }\end{array}$ & Linköping & $2016-09-16$ & $A, D, J$ & $\begin{array}{l}\text { Presenter, } \\
\text { discussion } \\
\text { member }\end{array}$ \\
\hline $\begin{array}{l}\text { Dialogue meeting for a fossil- } \\
\text { free transport sector }\end{array}$ & $\begin{array}{l}\text { The Swedish } \\
\text { Energy Agency }\end{array}$ & Stockholm & $2016-11-29$ & $\begin{array}{l}A, C, D, F, G, J, \\
K, L\end{array}$ & $\begin{array}{l}\text { Round-table } \\
\text { discussion } \\
\text { member }\end{array}$ \\
\hline
\end{tabular}




\begin{tabular}{|c|c|c|c|c|c|}
\hline Title/Topic of event & Organizer & Location & Dates & Participants & $\begin{array}{l}\text { Role of } \\
\text { authors }\end{array}$ \\
\hline $\begin{array}{l}\text { Hearing - Transition to a fossil- } \\
\text { free transport sector }\end{array}$ & $\begin{array}{l}\text { The Swedish } \\
\text { Energy Agency } \\
\text { and The Swedish } \\
\text { Transport } \\
\text { Administration }\end{array}$ & Stockholm & 2017-03-14 & $\begin{array}{l}\text { A, C, D, F, G, J, } \\
K, L\end{array}$ & $\begin{array}{l}\text { Round-table } \\
\text { discussion } \\
\text { member, } \\
\text { audience }\end{array}$ \\
\hline $\begin{array}{l}\text { GoBiGas - Future or epic } \\
\text { fiasco? (broadcasted seminar) }\end{array}$ & $\begin{array}{l}\text { The Royal } \\
\text { Swedish Academy } \\
\text { of Engineering } \\
\text { Sciences }\end{array}$ & Stockholm & $2017-02-21$ & n.a. & $\begin{array}{l}\text { Audience } \\
\text { (distance) }\end{array}$ \\
\hline $\begin{array}{l}\text { Biogas bus tour with biogas site } \\
\text { visits, gas car seller visit, and } \\
\text { meetings with politicians and } \\
\text { public servants, public } \\
\text { transport authority, bus } \\
\text { operators, biogas producers } \\
\text { and distributors }\end{array}$ & $\begin{array}{l}\text { Biogas Research } \\
\text { Center }\end{array}$ & $\begin{array}{l}\text { Västervik, } \\
\text { Läckeby, } \\
\text { Kalmar, } \\
\text { Mörrum, } \\
\text { Nymölla, } \\
\text { Helsingborg, } \\
\text { Wapnö, } \\
\text { Alvesta, } \\
\text { Växjö }\end{array}$ & $\begin{array}{l}2017-05- \\
17 / 18 / 19\end{array}$ & $\begin{array}{l}\text { A, B, C, D, G, H, } \\
\text { J, K }\end{array}$ & $\begin{array}{l}\text { Presenter, } \\
\text { audience, } \\
\text { discussion } \\
\text { member }\end{array}$ \\
\hline $\begin{array}{l}\text { Biogas solutions in the } \\
\text { agricultural sector - workshop } \\
\text { series with invited guests }\end{array}$ & $\begin{array}{l}\text { Biogas Research } \\
\text { Center }\end{array}$ & Linköping & $\begin{array}{l}2017-06-16 \\
2017-08-25 \\
2017-10-12 \\
2018-03-09\end{array}$ & $A, B, D, G, H, K$ & $\begin{array}{l}\text { Round-table } \\
\text { discussion } \\
\text { member }\end{array}$ \\
\hline $\begin{array}{l}\text { Project presentations with } \\
\text { industrial partners }\end{array}$ & $\begin{array}{l}\text { Biogas Research } \\
\text { Center }\end{array}$ & Linköping & 2017-09-05 & n.a. & $\begin{array}{l}\text { Presenter, } \\
\text { discussion } \\
\text { member }\end{array}$ \\
\hline $\begin{array}{l}\text { Biogas solutions in Norköping } \\
\text { - workshop series with invited } \\
\text { guests }\end{array}$ & $\begin{array}{l}\text { Biogas Research } \\
\text { Center }\end{array}$ & Norrköping & $\begin{array}{l}2017-12-13 \\
2018-02-07 \\
2018-03-22\end{array}$ & $A, B, D, G, H, J$ & $\begin{array}{l}\text { Round-table } \\
\text { discussion } \\
\text { member }\end{array}$ \\
\hline $\begin{array}{l}\text { Re-launch of the national } \\
\text { biogas strategy }\end{array}$ & $\begin{array}{l}\text { The Swedish Gas } \\
\text { Association }\end{array}$ & Stockholm & 2018-04-12 & $\begin{array}{l}A, C, D, E, G, I \\
J, K, L\end{array}$ & Audience \\
\hline $\begin{array}{l}\text { Public hearing on possibilities } \\
\text { for fossil-free fuels to reduce } \\
\text { the climate impact of the } \\
\text { transport sector }\end{array}$ & $\begin{array}{l}\text { The Swedish } \\
\text { Government }\end{array}$ & Stockholm & $2018-04-12$ & $C, D, F, G, J, K$ & $\begin{array}{l}\text { Presenter, } \\
\text { Audience }\end{array}$ \\
\hline $\begin{array}{l}\text { Scenario workshop on biogas } \\
\text { and electrification in public } \\
\text { transport }\end{array}$ & $\begin{array}{l}\text { Research project } \\
\text { on environmental } \\
\text { buses }\end{array}$ & Linköping & 2018-05-02 & $A, B, F, J, K$ & $\begin{array}{l}\text { Organizer, } \\
\text { presenter, } \\
\text { round-table } \\
\text { discussion } \\
\text { member }\end{array}$ \\
\hline
\end{tabular}




\begin{tabular}{|l|l|l|l|l|l|}
\hline Title/Topic of event & Organizer & Location & Dates & Participants & $\begin{array}{l}\text { Role of } \\
\text { authors }\end{array}$ \\
\hline $\begin{array}{l}\text { Biogas bus tour with biogas site } \\
\text { visits, bus manufacturer visit } \\
\text { and meetings with politicians, } \\
\text { biogas producers/distributors } \\
\text { and public utilities }\end{array}$ & $\begin{array}{l}\text { Biogas Research } \\
\text { Center }\end{array}$ & $\begin{array}{l}\text { Katrineholm, } \\
\text { Södertälje, } \\
\text { Stockholm, } \\
\text { Uppsala, } \\
\text { Västerås } \\
19 / 20 / 21\end{array}$ & $\begin{array}{l}\text { A, B, C, D, E, G, Audience, } \\
\text { H, J, K, L } \\
\text { discussion } \\
\text { member }\end{array}$ \\
\hline $\begin{array}{l}\text { LNG and LBG for long-haul } \\
\text { goods transport }\end{array}$ & $\begin{array}{l}\text { VTI } \\
\text { Transportforum }\end{array}$ & Linköping & $2019-01-10$ & n.a. & Audience \\
\hline $\begin{array}{l}\text { Resource efficient value chains } \\
\text { for Biogas - seminar with } \\
\text { invited guests }\end{array}$ & $\begin{array}{l}\text { Biogas Research } \\
\text { Center }\end{array}$ & Linköping & $2019-01-17$ & A, E, G, J & $\begin{array}{l}\text { Presenter, } \\
\text { discussion } \\
\text { member }\end{array}$ \\
\hline
\end{tabular}

Table 2. An overview of the conducted interviews.

\begin{tabular}{|c|c|c|}
\hline Actor & Description of actor & Data collection \\
\hline Tekniska verken & $\begin{array}{l}\text { Municipal energy utility that collects } \\
\text { substrates and produces biogas }\end{array}$ & $\begin{array}{l}\text { Interviews and joint workshops (2014-2018) with } \\
\text { three managers (R\&D director, marketing director, } \\
\text { business development manager) responsible for } \\
\text { biogas business development }\end{array}$ \\
\hline Volvo & $\begin{array}{l}\text { Vehicle manufacturer - producer of gas } \\
\text { trucks }\end{array}$ & $\begin{array}{l}\text { Interview in } 2017 \text { with director of environment and } \\
\text { innovation for Volvo trucks }\end{array}$ \\
\hline Svensk Biogas & $\begin{array}{l}\text { Municipality-owned distributor of biogas } \\
\text { in the Östergötland region }\end{array}$ & $\begin{array}{l}\text { Interview in } 2018 \text { with CEO in connection with } \\
\text { workshop }\end{array}$ \\
\hline Biogas Väst & $\begin{array}{l}\text { Biogas advocacy coalition - } \\
\text { collaboration platform between } \\
\text { different actors. The goal is to increase } \\
\text { production and use of biogas in Västra } \\
\text { Götaland region }\end{array}$ & $\begin{array}{l}\text { Interview in } 2017 \text { with business development } \\
\text { manager responsible for biogas development in the } \\
\text { region }\end{array}$ \\
\hline Fordonsgas & $\begin{array}{l}\text { Distributor of biogas in the Västra } \\
\text { Götaland region owned by the gas } \\
\text { incumbent Air Liquide }\end{array}$ & $\begin{array}{l}\text { Interview in } 2017 \text { with business development } \\
\text { manager }\end{array}$ \\
\hline Göteborg Energi & $\begin{array}{l}\text { Municipal energy utility that collects } \\
\text { substrates and produces biogas }\end{array}$ & Interview in 2017 with chief sustainability officer \\
\hline Swedegas & $\begin{array}{l}\text { Gas incumbent that owns the gas grid } \\
\text { that connects Denmark with the } \\
\text { southwest of Sweden }\end{array}$ & $\begin{array}{l}\text { Interview in } 2017 \text { with sales director and business } \\
\text { development manager }\end{array}$ \\
\hline Gröna Bilister & Lobby organization for green cars & Telephone interview in 2017 with CEO \\
\hline Scania & $\begin{array}{l}\text { Vehicle manufacturer - producer of gas } \\
\text { trucks and gas buses }\end{array}$ & $\begin{array}{l}\text { Interview in } 2017 \text { with business development } \\
\text { manager in connection with workshop; visit to site } \\
\text { and workshop in } 2018\end{array}$ \\
\hline
\end{tabular}




\begin{tabular}{|l|l|l|} 
Eon & $\begin{array}{l}\text { Incumbent energy utility that produces } \\
\text { and sells biogas }\end{array}$ & $\begin{array}{l}\text { Interview in 2017 with business development } \\
\text { manager in connection with workshop }\end{array}$ \\
\hline Purac & Biogas technology supplier & $\begin{array}{l}\text { Interview in } 2015 \text { with sales director and technical } \\
\text { director }\end{array}$ \\
\hline $\begin{array}{l}\text { Scandinavian } \\
\text { Biogas }\end{array}$ & Specialized biogas producer & $\begin{array}{l}\text { Interview in 2015 with R\&D director, marketing } \\
\text { director, business development manager }\end{array}$ \\
\hline Aga Linde & Gas incumbent & $\begin{array}{l}\text { Joint workshop and interview with business } \\
\text { development manager in 2016 }\end{array}$ \\
\hline $\begin{array}{l}\text { Gasum } \\
\text { Ministry of the } \\
\text { Environment and }\end{array}$ & Policy and regulatory agency & $\begin{array}{l}\text { Joint workshops during 2017 and 2018 as well as } \\
\text { interview with business development manager }\end{array}$ \\
\hline
\end{tabular}

\section{Appendix 2 - data on Swedish biogas production and distribution}

In 2005, sewage treatment facilities accounted for 43 percent of Sweden's total production of 1.3 TWh of biogas; landfills also accounted for a significant share. In 2017, the total production was 2.1 TWh, with significant growth in co-digestion facilities, which accounted for almost half of total production. A key for the growth of co-digestion systems has been access to organic wastes from both industries and private households. Diagram 1 shows the overall development of Swedish biogas production and its distribution across different types of production facilities. 


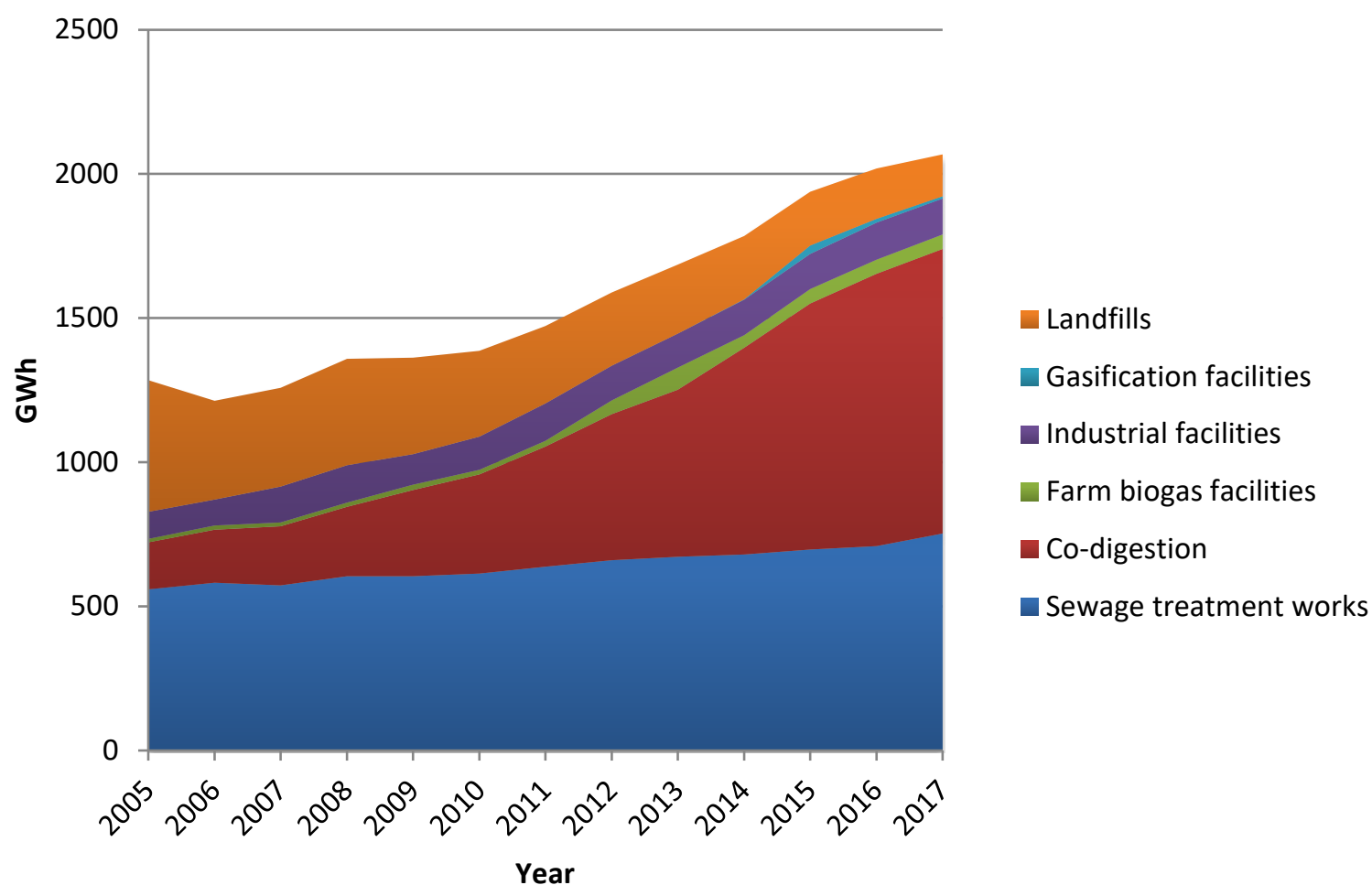

Diagram 1. Swedish biogas production per production facility category 2005-2017. Source: Swedish Energy Agency.

In 2017, there were 275 biogas production facilities in Sweden. Together, the 17 largest accounted for more than half of total production. The size distribution is heavily skewed, with a few relatively large units, mainly co-digestion and sewage treatment facilities, and many small ones. Approximately 62 percent of Swedish biogas was produced at publicly owned (mostly municipal) facilities. Sewage treatment is completely in public hands, whereas industrial facilities (using process waste/wastewater as substrates) and farm facilities (using manure) are predominantly private. For co-digestion, the ownership distribution was more equal: 21 privately owned facilities produced a total of $589 \mathrm{GWh}$ and 15 public facilities produced $398 \mathrm{GWh}$.

Diagram 2 shows the volume of upgraded biogas distributed via different channels. The data shows that the supply via filling stations that are open to car-owners (public filling stations) leveled out from 2013-2016 before increasing again in 2017, while the supply via bus depots has risen constantly during the last eight years. 


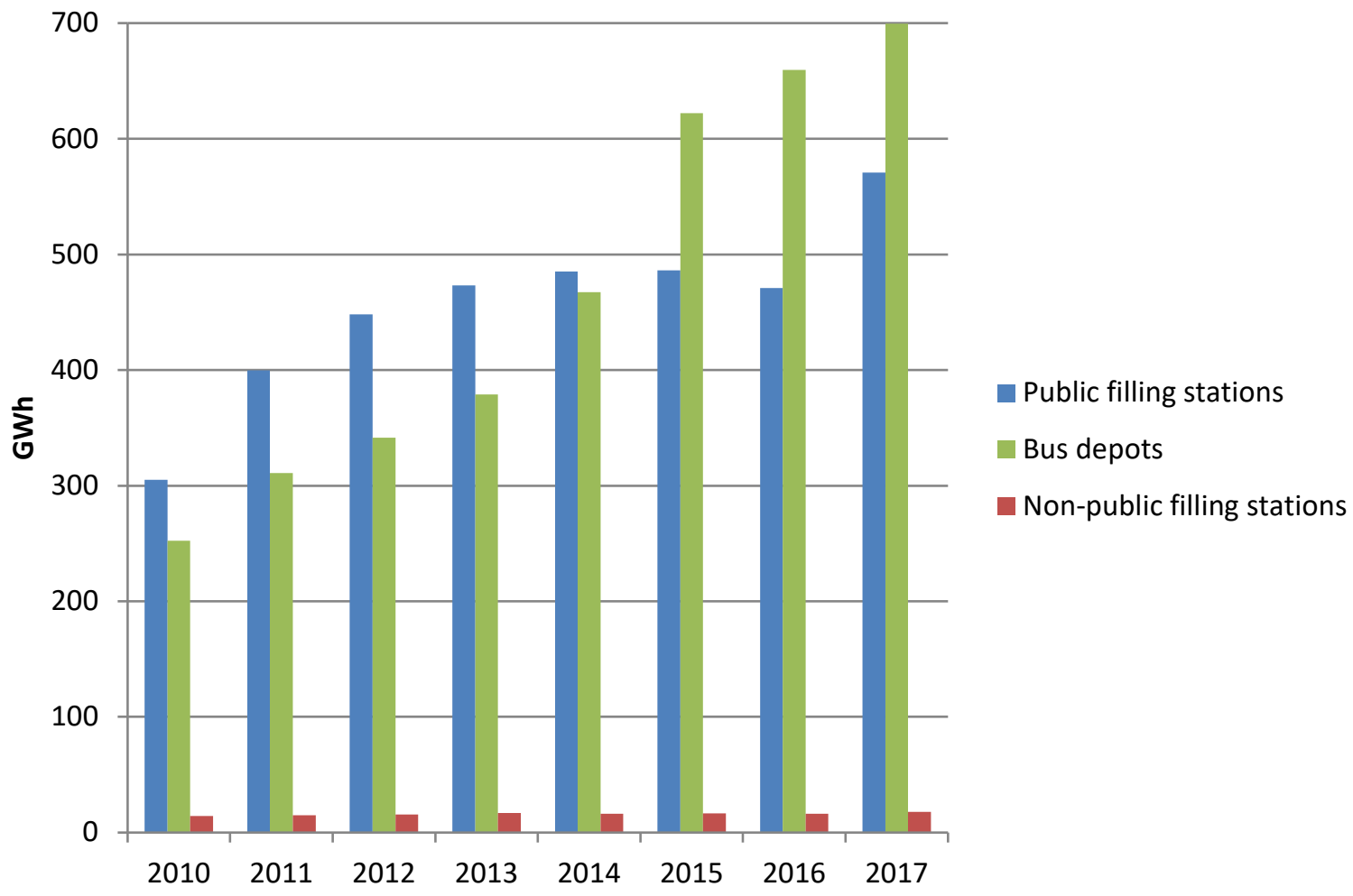

Diagram 2. Upgraded biogas for vehicles via different distribution channels, 2010-2017. Source: Statistics Sweden. 